UM Libraries Depository

||||||||||||||||||||||||||||||||||||||||||||||

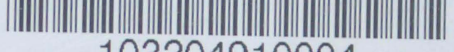
103204910004

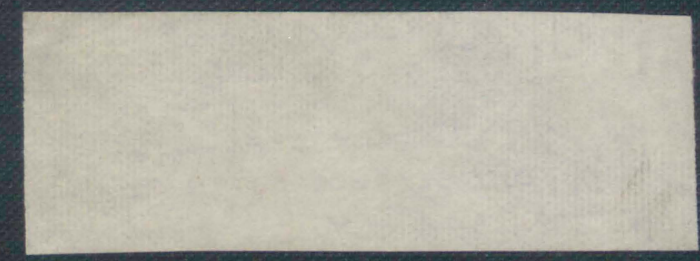




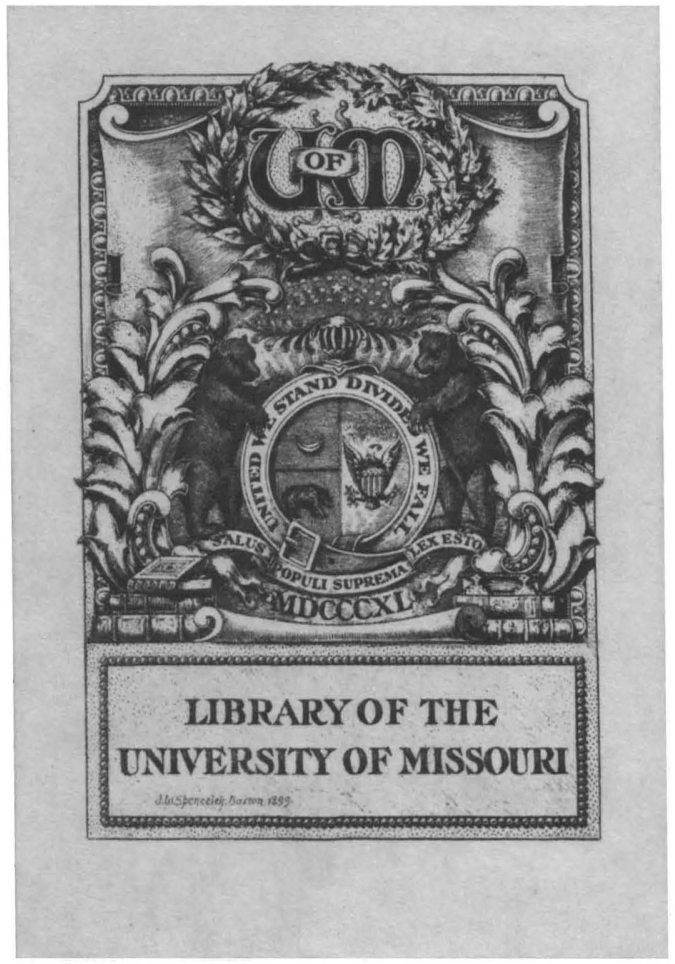

This Thesis Has Been

MICROFILMED

Negative No. T. 231

Form 26 

WOMAN IN THE EPIC

by

IUCIIE ARMER CARTER A.B.

SUBMITTED IN PARTIAI FULFILVENT OF THE

REQUIREMENTS FOR THE DEGRET OF

MASTER OF ARTS

\author{
in the \\ GRADUATE SCHOOL \\ of the \\ UNIVERSITY OF MISSOURI


$378,7 \mathrm{M} / 1$

$X C 246$

VOMAN--HER POSITTON AND THE PART SHE PLAYED.

A COMPARATIVE STUDY OF THE EPICS OF HOMER, VIRGIL, DANTE, AND MIITON. 
Within the pale of thet civilization which has grown up under the combined influence of the christian religion as paramount and what may be called the Teutonic manners as secondary, we find the idea of woman and her social position raised to a point higher than in the poems of Homer. But it would be hard indeed to discover any period of history, or country of the world, not being christian, in which women stood so high as with the Greeks of heroic age. It is hardy necessary to point out that in the primitive, as in the modern world, civilization was in the main fostered and advanced by women. The men were absorbed in war, the chase, and the struggle for existence. On the women devolved the training of the children, the transmission of national customs, and the traditions from age to age.

The women of Homer show very favorably when compared with the women of Asiatic Ionia and of Greece in the classical period. Simonides of Amorgos says that "a good woman was an exception". Hipponax covers them with bitter ridicule; and they appear in the worst light in the comedies of Aristophanes. The female characters of Homer, so thoroughly human, so feminine, bear witness to his godlike power of creating eternal types. They vary greatly, of course, in form and character, but all are so clearly defined, so harmoniously consistent with themselves in word and action, that they represent not only the beauty, the grace, and the sweetness of the women of all ages, but also their meanness, their folly, their artifice and treachery, their unbridled passions, and even their 
desperate cruelty and wickedness. In the main, however, the women of Homer, reared in simple patriarchal surroundings, their inclinations controlled by the sanctity of family life, are amiable and well behaved, eminently moderate, and correct in word and action. The lady of Homer is the true lady of all times and nations.

It would be a mistake to conclude from the high position held by some of the great ladies, such as Andromapche, Penelope, Helen, and Arete, that there was anything like equality between the sexes. The women of Homer had really no"rights", and their position was entirely defined by the will and requirements of men. Dependence on some man was the lot of every woman during her whole life, and there was no escape. From the tutelage of her father she passed into the hands of her husband who had absolute power over her. When he dies the grownup son succeeds to his father's rights. Telemachus, for instance, could have given his mother to any one of the suitors(I), and was well aware of his power; but he was restrained from exercising it, partly by affection, and partly by more mercenary motives. To Antinous, who urges him, he says, "It can in no wise be that I should thrust forth from the house, against her will, the woman that bare me and reared me." (2). And he adds, "Noreover, it is hard for me to make heavy restitution to Icarius" (penelope's father) "as needs I must if, of my own will, I send my mother away".
(1) Od. 2, 1.13 .
(2) Od. 2, 132 . 
If her husband was slain in battle, the widow became the slave of the conqueror, (I), however high her previous rank may have been. Hector paints in the gloomiest colors the condition into wilch the high-born princess Andromache must fall, when he shall no longer be near to protect her. "Yea, of a surety," he says," I know this in heart and soul; the day shall come for holy Ilios to be laid low, and Priam and the folk of Priam of the good ashen spear. Yet doth the anguish of the Trojans hereafter not so much trouble me, neitier Hecuba's own, neitier king Priam's, neither my brethern's, the many and brave that shall fall in the dust before their foemen, as doth thine anguish in the day when some mail-clad Achaian shall lead thee weepIng and rob thee of the light of freedom. So shalt thou abide in Argos and ply the loom at anothor woman's bidding, and bear water from fount Messeis or Hypereia, being, grievously entreated, and sore constraint shall be lald upon thee. And then shall one say that beholdeth thee weep: 'This is the wife of Hector, that was foremost in battle of the horse-taming Trojans when men fought about Ilios'. Thus shall one say hereafter, and fresh grief will be thine for lack of such a husband as thou hadst to ward off the day of thraldom. But may the heaped-up eartin be covering me in death, ere I hear thy crying and thy carrying into captivity." (2).

THe spirit in which war wag conducted in the Homeric times was much like that which is set forth in the book of Deuteronomy, 20, 13: "Thou shalt smite every male thereof with the edge of the sword; but the women and the

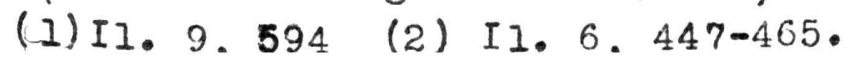


little ones, and the cattle, and all that is in the city, even all the spoil thereor, shalt thou take unto thyself". In the Fmbassy to Achilles, cleopatra is represented as urging her husband Neleager to defend his city "telling him all the woes that come on men whose city is taken; the warriors are slain, and the city is wasted by fire, and the children and the deep-giraled women are led captive by strangers".(I). Chryseis was captured from Thebes and given as prize of honor to Agamemnon, whose refusal to exchange her for a ransom of countless gifts from her old father the priest Chryses, brougint upon the Achaians the wrath of Apolio and countless woes. Thus also Briseis was taken for a spoil from lyrnessus; her husband and three brothers were slain, and she was taken as a prize by Achilles, who had killed her husband. (2). so also the royal mother of Andromache was taken with the rest of the spoil from Hypoplacian Thebes. (3).

The influence of the woman over her husband is entirely personal. Man's will is absolute, but frequently he listens to the wife he loves. When Arete, the Phaeacian queen, expresses her opinion of Odysseus, Lord Echeneus, the Phaeacian elder, defines her exact position as a beloved and respected wife. "Friends, the speech of our wise queen is not wide of the mark, nor far from our deeming, so hearken thereto. But on Alcinous here both word and deed depend." (4). To Odysseus Athene says of
(1) II. 9, 591-594.
(2) II. 19, 296
(3) II. 6, 426 .

(4) Od.11,342-346. 
Arete: "Alcinous took her to wife and honored her as no other woman in the world is honored, of all that nowa-days keep house under the hard of their lords. Thus she hath and hath ever had all worship heartily from her dear children and from her lord Alcinous, and from all the folk who look on her as on a goddess and greet her with reverent speech when she goes about the town. Yea, for she too hath no lack of understanding. To whomever she shows favor, even if they be men, she ends their quarrels. If her heart be kindly disposed to thee, then is there good hope that thou mayst see thy friends and come to thy high-roofed home and thine own country." (I).

And yet we know that the women of the epics were far from being kept in semi-oriental seclusion. Not only do women flock to the Scaean Gate of Troy to learn news of the war, (2), and form a procession to the temple for public worship, (3); they are also said to go out of the town to see a circus rider perform on four horses at once, (4), to carry water from the town spring,(5) and to wash clothes at the public troughs and at the river, (6) and in the harvest field they prepare the porridge for the reapers. (7) Women, evidently neighbors, come into the middle of the street and use harsh language of each other--" saying things true and false."(8). In time of extreme danger, when the warriors are without the gates of Troy, the women stand guard on the battlements of the city together with the old men.(9). The wife of Antenor, Theano, is priestess
(I) Od. 7, 63-77 (2) II. 6, 238
(3) II.6,296 (4) II. 15,683.
(5) $0 d .10,107$
(6) I1. 22, 155; Od.6,74.
(7) II. 18,560 .
(8) II. 20,253.
(9) II. 18,514 . 
of Athene.(1). The women of Homeric Greece clearly were far freer and more influential than their dautinters and successors of the historical period. spartan women indeed had more freedom, but in the true family life they do not seem nearly so important and influential as the Homeric women. Nothing in the poems, however, indicates the existence of a matriarchate in early Greece, but merely what modern readers would consider the most wholesome and natural family relations of the whole ancient world.

Arete, queen of the Phaeacians, is the center of the guests in the palace hall; Helen also comes to her hall as soon as she learns that guests have arrived at the palace. We may fairly infer that the great hall, the megaron, was the usual place of the Homeric wife and that she was not expected to withdraw to the women's quarters on the entrance of a stranger. Doubtless Penelope sat in the hall of her palace until her sultors became so numerous and importunate that she appeared to them but seldom. (2). There she sits by the fire for her talk with the disguised Odysseus on the night before the suitors are slain. (3). When Penelope appears formally to the suitors, she is attended by two handmaids;(4); and, similarly escorted, Andromache(5) and Helen(6) go to the tower by the scaean gate. Young women, as appears in the case of Nausicaa, are not expected to sit with the guests. The large company of fair women whose ghosts Odysseus saw in Hades of them-
(I) $I 1.6,300$
(2) $0 d .\left\{\begin{array}{l}18,164 \\ 15,516\end{array}\right.$
(3) Od. 19,55 .
(4) $0 d .1,331 ; 18,207$.
( 5 ) $11.22,450$
(6) II. 3,143 
selves would make it impossible for us to think of Homeric women as of little importance.(1).

The position of woman in general forbids us to believe that she was bought and sold in marriage, although her father did receive gifts from her suitors, and AristotIe says that the ancient Greeks bought their wives. ( Tàs ruvấkas '́w vỗvTo_Politics, I. I., 8, 12) No one can suppose that Nausicaa was to be given to the highest bidder and that Arete and Nausicaa were to have no voice in the decision. Indeed the poet tells us that Nausic aa has had many noble suitors, but that she, not the father (2), slights them. Nothing could be more inconsistent with their family life as depicted than to suppose a sale of the daughter, and in particular Alcinous is so charmed by Odysseus that he says frankly that this is just the sort of man he wants for a son-in-law, and he is willing to accept him, with no property, as a suitor for his daughter's hand, altho many of the Phaeacian nobles are wooing her.(3). In general, however, the father expected gifts, and the poet applies to maidens the epithet "cattle-bringing" ( 'a $\lambda \phi \in \sigma l \beta O L a l$ ) . (4). This custom was so general among Indo-European peoples that we should expect it as wo find it in Homeric Greece. Odysseus' parents gave his sister in marriage to a husband on the island of Same and received " countless gifts"

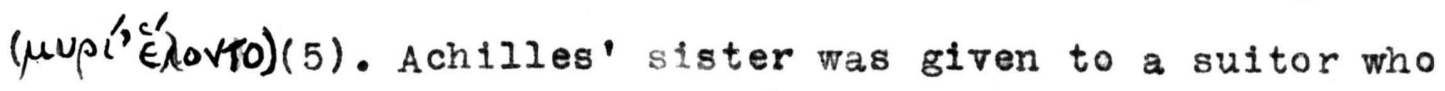
gave" boundless wedding gifts" ('́́์ Va) (6).

(1) Od. 11,225-329 (2) 0d. 6,283 (3) 0d. 7, 311; 6,284.(4) II. 18, 593 (5) Od. 15, 367 (6) II. 16, 178;190; Od.II, 
The suitor Antinous urges that Penelope should marry him "whom her father hids, and who is pleasing to herself", (I), but elsewhere she should marry" the man who is bravest and offers the most gifte".(2). The question cannot have been simply who would pay the largest price, or the auction would have been soon over. At last, as we know, Penelope demanded no gifts at all, but said she would wed him who most easily should string the old bow of Odysseus and shoot an arrow thru a mark formed by axes.(3). Penelope had invited gifts from these suitors, (4): Antinous gives her a beautiful embroldered robe with twelve brooches, Eurymachus a Iong necklace of gold and amber, Eurydamas, earrings, $x d$ each of the other suitors makes some present to the lady. But these are not to be returned in case of her marriage to another than the giver; they are gifts without condition. Such gifts she declares to be usual, tho' cormonly they would be given to the bride's father. Nestor's sister was offered as wife to anyone who should drive from Phylace the cattle of Iphiclus; $(5)$; in this task the geer Mel ampus succeeded, but transferred to his brother Bias his claim to the hand of Pero. Bellerophon is accepted as son-in-law by the Lycian king, without gifts, when he has killed the Chimera and rendered other services.(6). Othryoneus cme to the war as a Trojan ally receiving from king Priam the promise of Cassandra to wife if he should drive the Achaeans from Troy. (7).
(1). Od.2, 114.(2) Od.16,77
(3) 0d.2 1,75
(4) Od.18,2 78-301
(5) Od.11,289
(6) II. 6, 192
(7) II. 13, 363-6? 
He is slain by Idomeneus who mockingly says in exultation: "Othryoneus, verily I praise thee above all mortal men, if truly thou shalt fulfil thy promise to Priam, son of Dardanos, who promised thee his daughter. Yea, and we likewise would promise as much to thee and fulfil it, and would give thee the fairest daughter of the sons of Atreus and bring her from Argos and wed her to thee, if only thou wilt aid us to take the well-builded city of IIium."(I). Similarly, Agamemnon offers to Achilles, when he is sulking in his tent, if he will give up his wrath and fight for the Achaians, whichever of his three daughters he may choose, without gifts from the suitor, (2), ('a $\vee$ '́ $\in$ S $\vee$ ov ), while the father will bestow such presents $(\mu \in\{\lambda(a)$ (3) on the bridegroom as never yet were given with a daughter, namely seven well-built towns.

It is in the interest of the woman that the law of marriage should be strict and that marriage should be single. Among the Homeric Greeks, we have not the slightest trace of polygamy; or of a woman taken from her husband and made the wife of another raan during his lifetime. The suitors always urge Penelope to remarry on the ground that Odysseus must be dead and that there is no hope of his return. A presumption of death brought near to surety must, under the conditions of human affairs, be taken to suffice. But in the case of Agamemnon, there was no presumption of death; and, accordingly, the act of Aegisthus is described by zeus as a double outrage made up of two crimes, the last part of it being the murder, but the first the simple fact of seduction and adultery. (4) 1) II.13,374-380 (2) I1,9, I46 (3) II.9,I47. (4) Od. I, 36 . 
Even the bodily abstraction of the wife, as in the case of Helen, does no more than destroy the marriage for the time. When she is recovered, she assumes her domestic place. There is no such thing as a formal and final dissolution of the marriage except by death. In the narrative, and by the Trojans, as weil as by herself, Helen is called the wife of Paris; yet never do we find this acknowledgment in the mouth of a Greek. Hector even calls Helen the wife of Menelaus, (1), but this may mean the past wife. Menelaus never treats what has occurred as setting hin free from his obligations to Helen. And the long resistance of Penelope presented to us in the Odyssey as a central object of our interest and admiration, could not have been chosen by the poet unless it had been in conformit with the actual Greek idea of a genuine and lofty virtue.

Concubinage is practised by some few, and, as far as we are informed, by only a few of the Greek chieftains before Troy. Of actual domestic concubinage we have no example. Agamemnon threatens to take Briseis home with him (2); this, however, is done under angry excitement. In the assembly, he thinks it necessary to give the reason for a proceeding which he apparentiy perceived would require a justification; and it is that he prefers her in all respects to Clytaemnestra. But we have no trace, in the return, of any chief's carrying a concubine home with him. Laertes, from an apprehension of conjugal trouble, respected the maidenhood of his young bondwoman.(3). These instances, if they show that the man was not exempt from passion, bear very emphatic testimony to the position of $(I 1.3,53$ (2) II.1,29,113 (3) 0d.1, 433 


\section{the wife.}

The relations of youth and maiden generally are indicated with extreme beauty and tendemess in the IIiad(I); and those of the unmarried woman to a suitor are so portrayed, in the case of the incomparable Nausicaa, as to show a delicacy and freedom that no period of history or state of manners can surpass.(2). On her return home, Alcinous, far from reproving her, thinks she should have shown more foward ness to entertain the shipwrecked stranger. The very fact that wanton and haughty suitors always confine themselves to moral pressure and profess to submit to the choice of Penelope, is of itself a probable witness to the recognized free agency of the woman of the age depicted.

Marriage in Homer is the very pivot of life. War is the deadly enemy of woman. On the capture of a city, her lot is exile and the conqueror's bidding.(3). The familiarity of this idee renderg it remarkable that we should not hear much more than we do of concubinage among the Homeric peoples. We have a single case of a woman who attempts the breach of her own marriage vow; it was Anteia, the wife of Proetus, and she was of phoenjcian blood. (4).

Thus, then, we have in the Odyssey and Iliad a picture of Greek marriage as to its unity, freedom, and perpetuity, as to the restraints upon it, and as to the manner in which breaches of it, and substitutes for it, were regarded. This picture, so striking in itself,
(1) II. $18,567,593 ; 22,127-28$
(2) $0 d .6,275-288 \cdot(3)$ II.9,

590-594. (4) II. 6, 160. 
becomes yet more so by comparison with eastern manners. It is also in glaring and painful contrast with the lowered estimate of woman among the Greeks of the classical period and with their imorality.

More important than any particulars is the general tone of the relation between husband and wife. It is thoroughly natural: full of warmth, dignity, reciprocal deference, and substantial, if not conventional, delicacy. The fulness of moral and intelligent being is alike complete, and alike acknowledged on the one side and on the other. Nor is this description confined to the scenes properly Hellenic. It embraces the conversation of Hector with Andromache, and is no where more applicable than to the whole character and demeanor of Nausicaa- delineations probably due rather to the Hellenic experience of the poet than to any minute observance either of Phoenician or of Trojan manners. Of rude manners to a woman there is not a real instance in either the Iliad or the Odyssey. And to this circumstance we may add its true correlative, that the women of the Homeric age are truly and profoundly feminine. As to the intensity of conjugal love, it has never passed the climax which it reaches in Penelope and Odysseus.

It appears to be at least open to question whether women were not capable of political sovereignty.(1). The suggestion of the text seems to be that Chloris was queen in Pylos when Neleus married her; and the mention of Hypsipyle with Jason is best accounted for by supposing, conformably to tradition, that after the loss of all the men, she reigned in Lemnos.(2). On the departure of 
Agamemnon, clytaemnestre was left in charge with the bard as an adviser;(1); and in Ithaca, Penelope had a similar regency, apparently, with the aid of Mentor.(2).

As for the occupations of women, the poems show that most of the work within the house was done by women, and that this included not only the care of the children and the ordinary house work of modern times, and embroidery, but also much that is now done by machinery, as the grinding and pounding of grain, and the carding, spinning, and weaving of wool and flax.

Spinning and weaving were occupations that were never ended. From the labor of sewing, however, women were relieved, at least for the most part, as in the making of Homeric dress, little cutting and sewing were required, and probably no fitting. Buttons and hooks and eyes were unknown. Sewing is mentioned but once, when the poet says that the aged Laertes wore a sewed or patched tunic (

Women carried water from the spring: thus a score of them went to the spring from the house of Odysseus, (4), and the Laestrygonian princess is on her way to the spring for water when she meets Odysseus' comrades.(5). The grinding of grain and the carding of wool were menial; but spinning, weaving, and embroidery were the proper occupations for princesses, for Penelope,(6), Helen(7),

(1) $0 d .3,263,268$ (2) Od.2,225-27; 19,317; 20,129-133. (3) Od.24,228 (4) Od.20,158 (5) Od.10,107 (6) Od.2,94 (7) II. 3,$125 ; 0 d .4,124$. 
Andromache, (1), and Arete;(2); the Phaeacian women were as proud of their weaving as their husbands were of their ships.(3). Penelone's web must have been very elaborate if her suitors were satisfied to wait three years for its completion.(4). Nausicaa joined with hermaidens in washing the liren, not as a menial toil, but as a part of a day's pleasant exercise bya the river.(5). Fiven the carrying of a considerable burden is assigned to women, as when Arete sends three of her women to bear to the ship the gifts that have been bestowed upon Odysseus. (6). Similarly, Telemachus is asked to send women to bear the presents that he received from sparta.(7).

The amusements and recreations of the women in the Homeric epics were, like their lives, simple; they had few" social events". But they met at the harvest home and at vintage festivals, (8), and at marriage feasts, (9), as well as by the washing troughs and near the river side. The maidens danced with the youths. Thus in the relief on the mighty shield which Hephaistos made for Achiliss we find the representation of a joyous dance.(10). Hermes fell in love with polymele who was noted as "beautiful in the darce". (II).

Perhaps we may get a better idea of woman, her poition, and the part she played in the Iliad and the Odyssey, if we review separately the principal feminine
(1).II.22,440
(2) $0 d, 6,306$
( 3 ) $0 \mathrm{~d} \cdot 7,110$
(4) $0 d .2,106$
(5) $0 d \cdot 6,26$
(6) $0 d .13,66$ (7) 0d.17.75
(8) II.9, 534 ;
$18 / 567 .(9)$ II.I8,494 (I0)II.18,590-606
( II) II.16, 180 . 
characters of the two epics. Ten types of women are clearIy drawn by Homer; for some he has used but a few Iines, and no one of these is repeated: Helen, Andromache, Penelope, Hecuba, Arete, Nausicaa, Clytemnestra, Briseis, Chryseis, and Eurycieia.

Fair Helen of Troy--often called Argiee Helen from her early home--is beautiful, fascinating, with great tact but little conscience, the quick-witted mistress of her household, and yet easily influenced. She is not greatly troubled in soul by the fact that she is the cause of the war. She applies to herself such harsh

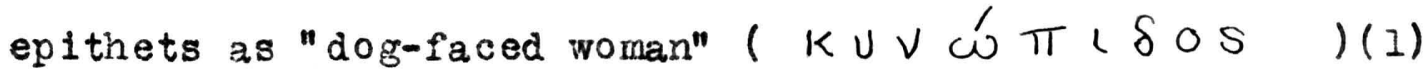
and "dog";(2); and wishes that she had died before causing al this trouble.(3). In general, no one has the heart to reproach her, tho Achilles, addressing the dead patroclus, calls her horrible.(4). When she goes to the great tower by the scaean ete on the first day of battle, for a view of the conflict on the plain, Priam, who has most to lo $\phi$ se by the war--his sons and daughters, his royal ranis and vast possessions--addresses her in affectionate terms:

" Come hither, dear child, and sit by me, that thou mayest see thy former husband, thy kinsmen and thy friends. Thou art not to blame in my 8 ight; the gods are to blame who brought upom me the tearful war of the Achaians." (5) Similarly, Hector, tho' he curses his brother Paris for bringing Helen to Troy, -wishing that he had
(1) IL. 3,180
(2) II.6,356
(3) $[1.3,173$
(4) II. 19,325

(5) I1.3, 162 . 
never been born, (1), and even praying for his death, (2) -. yet has no word of reproach for Helen herself. Menelaus, too, has no rebuke for Helen, but welcomes her back to his home, with no reproaches, and accepts the view which Helen herself presents when she says that Aphrodite inspired in her blind infatuation "when she led her to Troy, away from her fatherland, leaving her daughter, her home, and her husband, who was inferior to no other either in mind or comeliness".(3). Helen presents a similar view to rector when she says that zeus put an evil fate upon her and Paris that they should be the subject of s ong for men of coming time.(4).

The poet gives no description of Helen's beauty. His method is simple yet singularly effective. He does not, like modern poets, give details of her various charms. We know not whether she was dark or fair, her eyes blue, brown, or grey. He does not attempt to describe her charms, but her shows us their effect and everyone is left to find his own Helen in his own surroundings. It has been observed that no more satisfactory evidence of her beauty could be given than the words of the aged counsellors of Troy, as she approached the Scaean Gate. The aged Priam and the sages of Troy sit sunning themselves on the battlements by the Scaean Gate,"like grasshoppers on a tree in the forest, uttering their lily-iike voice".(5). There was probably not one of them who had not lost son, brother or kinsman in this bloody war--not one who did not for $e^{e}$ see the fall of sacred Ilium, his native city, and the
(1) $11.3,40$
(2) $I 1.6,281$.
(3) $0 d .4,261$
(4) I1.6,357
(5) I1.3, 
captivity of his wife and children. And ret, such was the almost demoniac influence of her dazzling and bewildering beauty, that they can see nothing for the moment but the radiant loveliness of the woman before them. As they behold fielen coming to the tower, followed by her two handmaids, "they softly spoke winged words one to another: It is no matter of blame that for such a woman the Trojans and well-greaved Achaians suffer long; mightily is she like the immortal goddesses in countenance". Reason of course, quickly $r$ esumes its sway, and they add:"But yet, though such she is, let her go in the ships and not remain as a bane to us and our children after us"(1). Although Helen could not but be conscious of the extraordinary fascination which she exercised over all who saw her, there is nothing trlumphant or coquettish in her bearing. On the contrary, she addresses the aged Priam with touching humility: "Reverend art thou to me and dread, dear father of my lord. Would that sore death had been my pleasure when I followed thy son hither and left my home, and my kinsfolk, and my daughter in her girlhood, and the lovely companions of mine own age. That was not to be, therefore I pine away with weeping."(2). Helen's tact is shown by her courteous reference to Menelaus in connexion with her going to Troy, already quoted (3) " she must have been infatuated or she would not have left such a husband". She is charming, too, when she gives to the young Telemachus on his departure a robe that her own hands have wrought, for him to give
(1) $11.3,156-60$
(2) $11.3,172-75$
(3) $0 d .4,261$. 
to his bride on his marriage.(1). She never is made to utter a harsh or cutting word, except indeed to Paris on his shrinking from the battle.(2).

In the la st book of the Iliad we find her among the Trojan women at the official solemn wailing by the lofty pyre on which lay the body of noble Hector. When his wife, Andromache, and his mother Hecuba, had exercised their right of precedence, then Helen led the sore lament. (3).

Homer, of course, tells us nothing of the fate of Helen between the death of Hector and the fall of Troy. After that event, no doubt, she was at once delivered up to her lawful husband, Menelaus. He, with a wise charity, knowing that she was the victim of Aphrodite and the Fates, receives her back with all love and honor; and in the Odyssey we find her reinstated in her former home in sparta.

And here we see our last of the divine Helen. We leave her in the greatest prosperity, indulging her sweet kindly nature in speeding the parting guest, Telemachus, whom she had so royally entertained, with bright augury for the future.(4). We leave her loved and honored by her husband and her people, as tho' she had never known sin and its attendant sorrows. Her unrivaled beauty, already celebrated thru the world for some three thousand years, her consummate elegance of form and movement,
( I) $0 \mathrm{~d} .15,126$
(2) $I 1.3,428 ; 6,350$
(3)
II. $24,762-75$

(4) Od.14,172 
her keen appreciation of all that was good and noble in her surroundings, her gratitude for sympathy and kindness, and above all, her sweet penitential remorse for her past transgressions, render her one of the most interesting and charming figures in ancient story.

The Right Honorable William E. Gladstone, in speaking of Helen said,(1), "Upon the whole, I think that no one foring his estimate of Helen from Homer only could fall into the gross error of looking upon her as a type of depraved character." He sumed up his estimate of Helen in almost exaggerated panegyric: "Her self-abasement and self-renouncing humility come nearee, perhaps, than any other heatinen example, to the type of christian penitence." (2).

There is not in all literature a more exquisite plcture of a gentle, modest, and affectionate woman than that of Andromache, the loving wife of the noble Hector and mother of the little Astyanax. She has all the delicacy, sweetness and refinement, the heart and soul devotion to her husband and her child, which we only expect to find in periods of the best and highest civilization. Her tenderness and tears, her sact and undeserved fate, fill us with unwonted pathos, and we feel angry with the gods for laying such a weigit of misery on such a tender and innocent soul. We see her only three times in the Iliad and yet how fully we seem to know her and how warmly we love her.
(1) Juventus Mundi, P. 507
(2) Ibid. p. 508 . 
20.

Hector and the little Astanax are Andromache's all. (1). Hector is the chief of the Trojan leaders and she shares Whis cares and anxieties. Interested in all that is his, she often feeds his horses on his return from the field of strife.(2). On the first day of battle, with her infant son and the nurse she has gone to the scaean Gate of the city in the hope of learning tidings of the conflict and her husband. There she learns that he has come to the city with a message for Queen Hecuba, and she hurries to meet him just after he has sought in vain at their home and is hastening to the fray. Hector smiles, looking upon his child in silence, but Andromache, weeping, stands by him, clasps his hand and says, "O dear my lord, this thy hardihood will undo thee, neither hast thou any pity for thine infant boy, nor for me forlorn that soon shall be thy widow; for soon will the Achaians set upon thee and slay thee." (3). She then reminds him that he is to her not only husband but also father and brother, and urges nim to take his stand within the city and from the wall to direct its defense. He replies that he remembers this; but he cannot remain away from the battie. He knows that the time will come when Ilium shall fall, and he grieves not so much for Hecuba, nor Priam, nor his brothers, as at the thot of the lot that is to befall her-.--to weave at the bidding of another, or to carry water from the springs of Argos or Thessaly. He caresses her and bids her: "Dear one, I pray thee be not of over-sorrowful heart; no man against my fate shall hurl me to Hades; only destiny, I ween, no man hath escaped, be he coward or be he valiont,
(1) $I 1.6,429$
(2) $11.8,187$
(2) $11.6,407-410$ 
when once he hath been born. But go thou to thine house and see to thine own tasks, the loom and distaff, and bid thy handmaidens ply their work; but $f o r$ war shall men provide, and I chief of all men that dwell in IIios"(I). And so the noble pair separate, never to meet again in life. Even in that dread hour we see that Andromache preserves the moderation of the Greek woman, ( ai $\delta \omega ́ s$ ). of course she could not but pray him to abide within the impregnable walls of sacred Ilios, and not to go forth to certain death, for the fate of all three hung upon his decision. But she must have known in her heart of hearts, that Hector caild not yield to her prayer. Had he do ne so he would no longe $r$ have ben her Hector, nor the great example of honor to her boy. After the natural inevitable outpouring of her despair, according to her lord and master's bidding, she quietly returns home with her little son to attend to her tasks, as he was doing to his own.

We see and hear nothing more of the afflicted wffe and mother until her worst fears are more than realized and the dread battie cry rings thru the doomed city that betokens that some calamity has befallen the Trojans. Her heart fears the truth and she hastens to the tower only in time to see Hector's body dragged to the Achaian camp behind the chariot of Achilles. "Then dark night came over her eyes and shrouded her, and she fell backward and jasped forth her breath". (2). Recovering from her swoon, she bewails with deer sobs the fate $a$ her son, left 


\section{2.}

without a father.(1).

Once again we meet with the bereaved Andromache, at the funeral rites of Hector, after inis body has been ransomed from Achilles by the aged Priam. Among the white-armed Trojan women, Andromache, in right of her precedence as wife of Hector, leads the lamentation. Holding his head in her arms, she bewails him, herself and their son, and the city too, "for thou art verily perished who didst watch over it, who guardedst it and kept est safe its noble wives and infant little ones."( $\mathcal{L})$. The mutual affection and confidence of pector and Andromache are truly ideal.

For centuries, the well-known type of the devoted wife, faithful thru long years of uncertainty as to the fate of her husband, although surrounded by high-born and persistent wooers, has been Penelope. Homer has drawn her portrait with a loving as well as a skilful hand, and tho' she does not excite our interest in the same degree as Helen or Andromache, we regard her with esteem and admi ration. Her position is difficult in the extreme. In the Odyssey she is really under the tutelage of her son Telemachus, and he is continually called upon by the suitors to exercise his lawful authority over her and compel her to choose one of the Ithacan princes. (3). Telemachus by no means denies that he has the right to dispose of his motheris hand. He knows, and on some occasions exercises his power. Rather harshly, when she has come down into the hall of the pabace and begged the minstrel to cease from chanting the sad tale of the Trojan war, he 
bids her "to go to her chamber and mind her own tasks, the loom and the distaff, and bids her handmaids ply their work" (I). "But speech," he added, "shall be for all men, but for me in chief, for mine is the lordship in this house." It is only his affection for his mother that prevents him from complying with what would seem to every Achaean a reasonable demand. Nor has she any support in her determination to remain true to the memory of her husband, in her father or brothers, who all exhort her to marry Eurymachus "for he out oes all the wooers in his presents."

There is a tendency on the part of some to mock the constancy of Penelope and to accuse her of something like "flirting" with the suitors. Nothing can be more unjust. She stood alone before a host of adversaries. Arrayed against her were traditions which imperatively pointed out to her, as a clear duty, to give herself to the wealtiniest suitor; the parting injunction of her husband (2) ; the evident wish of her son; the advice of her father and brothers; and the persistent courtship of the suitors, who claimed her hand by a generally acknowledged right. Yet twenty long years, without any tidings from her absent lord to encourage her, she resisted all those potent influences. When it seemed to all men certain that Odysseus had long been dead, and she had no excuse to make except the longing for "the perfect excellence" of the husband of her youth, who shall blame her for cajoling her persecutors with false hopes, and delaying by the artifice of the web, the hated marriage for a few years 
longer? The suitors complain, saying, "She gives hope to all and makes promises to every man and sends messages to them, but her mind is set on other things?" that is, on keeping her troth to the very last. Of course she does deceive the $\mathrm{m}$.

That the suitors desired her for her beauty, her wisdom, and her skill in embroidery is evident thru the whole of the Odysiey. Theycompare her to Artemis or golden Aphrodite;(I); their hearts swell with joy at the sight of her. Eurymachus, the best of the suitors, addresses her thus: "Daughter of Icarius, wise Penelope, if all the Achaians in Iasian Argos could behold thee, even more suitors would be feasting in thy halls tomorrow; for thou dost excell all woman-kind in beauty and stature and within in wi sdom of mind." (2).

But it was not only her great beauty and manifold acomplishments that made her a desirable consort. Now that Odysseus was no more, Telemachus too young to wield his fatheris sceptre over the chiefs of I thaca and the Isles, the husband of Penelope might reasonably hope to succeed to the $\gamma \in$ pas, the suzerainty over the other princes, which had been enjoyed by Odysseus himself.(3).

Penelope shows high courage, as well as prudence and patient endurance. She bravely defends Telemachus against the suitors and sharply rebukes Telemachus himself for allowing his quest, Odysseus in disguise, to be evil entreated in the halls. (4).
(1) Od. 19,54
(2) $0 d .18,245-49$
(3) $0 d .22,49-53$

(4) Od. 16,418. 
She chides Antinous and reminds him that his father had been saved from the wrath of his own people by Odysseus who received him as a suppliant.

But although she struggles with might and main against fearful odds, she knows and feels that she is doomed. "The night shall come," she says," when a hateful marrlage shall find me out, me most wretched, whose good hap Zeus hath taken away". When the artifice of the web has failed, she gives up all hope, all resistance. Then bringing forth Odysseus' old bow, she announces the contest. But Although she reluctantly gives up the long, long, apparently hopeless struggle, and submits to fate, her love is unshaken. The memory of her lost husband is dearer to her than $\mathrm{y}$ of the lordly youths, who seek her favor with countless gifts, ( $\left.\mu \nu \rho i^{\prime} a \stackrel{c}{\epsilon}^{\prime} \delta v a\right)$. She longs for death as the only escape from a marriage with another. "Would that the spirits of the storm would snatch me frow the sight of men, or that the fairtressed Artemis would strike me with her gentle darts, that so, with a vision of Odysseus before my eyes, I might even pass beneath the gloomy earth, nor ever make a baser man's delight." (I). If any doubt could enter our minds of the entire freedom of Penelope from any penchant for any of the wooers, even for Antinous, "whose words more than all the rest were pleasing in her eyes", it must now be dispelled. When she hears of the ghastly massacre of the princes, of the hanging of the faithless maids and the (1) $0 \mathrm{~d} .20,77-82$ 
disgusting mutilation of the treacherous Melanthus, she summons Eurycleia and says : "Iet us go, that I may see the wooers dead and him that slew them"(I).

If Odysseus showed suspicious wariness on his return home, Penelope showed no less caution.(2). Right well did they deserve their epithets, he of (6f manydevices), and she of ' $\epsilon \chi \chi^{\prime} \in \phi \rho w$ (prudent, reserved). When she had come down from her chamber to where her husband sat, she debated in her mind whether or not she should receive him. "And long she sat in silence, for she knew him not, for that he was clothed in vile raiment".(3). Telemachus, astonished at her cold bearing, rebukes her: "Mother, hara mother, of ungentle heart, why turnest thou away from my father?-..--No other woman in the world would thus harden her heart to stand aloof from her lord, who after much travail had come to her in the twentieth year. But thy heart is harder than stone". (4). There was some excuse for her. Odysseus, no doubt, was greatly changed in twenty years of war and suffering on land and sea. Even when the house-dame, Eurynome, had "bathed the great-hearted odysseus, annointed him with olive 0il, and cast about him a goodly mantle and a doublet", even then Penelope would not lay aside her susplcion, and Odysseus, sorely grieved, reproaches her: "Good lady, surely to thee above all woman-kind the 0lymplans have given a heart that connot be softened."(5). Then at last she is convinced when Odysseus describes the hed that he himself had wrought.(6). "Her knees loosened
(1) $0 d .23,83$
(2) $0 d .23,90 s q$.
(3)
(5) $0 d .23,166-7$
(6) $0 d .23,183-204$. 
and her heart melted within her, as she knew the sure tokens that Odysseus showed her. She burst into tears, ran straight to him, cast her arms about him, and kissed his head". (I). And she pleade with him, "Be not thus angry with me because I did not welcome thee gladly as I do now, when first I saw thee. For always my heart shuddered for fear some man should come and deceive me, for many there be that devise gainful schemes and evil"(2). Herewith the perils of Odysseus, the sorrows of Penelope, are ended and aII is weIl as far as their relation to one another is concerned.

Such was Penelope-- a woman of unusuaf strength of character as shown in her long years of devotion to her absent lord, and in her courageous resistance to the powerful influences which almost compelled her to resigh her hopes and to accept a hateful marriage. Her caution, when Odysseus at last reveals himself, appears to us excessive; but when her doubts and fears are dispelled, she is full of tenderness and affection for the dear, sore lymissed husband of her youth. Well does she deserve the warm eulogy of Agamemnon's shade in Hades; "Ah, happy son of Laertes, Odysseus of many devices, yea, for a wife most excellent thou hast gotten, so good was the wisdom of steadfast Penelope, daughter of Icarius, that was duly mindful of her gentle lord. Whereforethe fame of her virtue shall never perish, but the Immortals will make a graclous song in the ears of men on earth to the fame of steadfast Penelope." (3).

(1) $0 \mathrm{~d} .23,205-08$ (2) $0 \mathrm{~d} 23,213-7$ (3) $0 \mathrm{~d} \cdot 24,192-98$ 
In Hecuba, we see the aged wife of Priam, mother of the great Hector and Paris, and seventeen other sons and daughters. She is almost exciusively the mother, pious, tenderhearted, and loving, yet a very tigress in the defense of her children;(1); far more careful of the life than the honor of her husband and her favorite son, the glorious

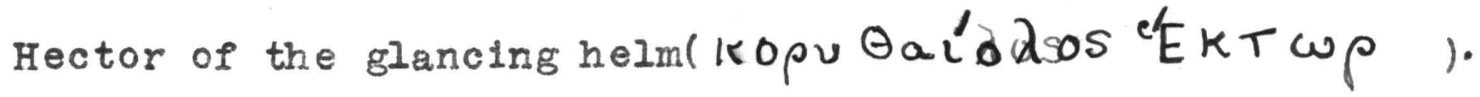

When Hector think it his duty to himself and his country to meet the terrible Achilles, Hecuba does all that she can, and far more than she ought, to turn him from his high resolve. If anything could have prevailed against his sense of honor, it would have been her piteous entreaties, (2). With tears and prayers, she goes to the temple of Athene, bearing splendid embroidered robes, which she gives to the priestess, Theano, fair of face, who lays them on the knees of the fairhaired thene, begging her in piteous terms to have mercy on the city, and on the Trojans' wives and little children. "But Pallas Athene denied the prayer" (3). When Hector is slain, her passionate grief knows no bounds: "she tore her hair and cast from her her shining veil and cried aloud with an exceeding bitter cry".(4). Iife seems no longer dear to her: "My child, Ah, woe is me: Wherefore should I live in my sorrow, now that thou art dead, who night and day wert my boast thru the city and a blessing to all ."(5). And again at the official wailing over Hector's recovered corpse, she
(1) $11.24,212$.
(2) $I 1.22,82-89$
(3) II.6,293
(4) $11.22,406$
(5) $\mathrm{I} 1.22,431-35$ 
leads the loud lament: "Hector, of all my children far dearest to my heart." (I).

When Priam nobly resolves to 80 to the tent of the fierceslayer of his son, and, by a magnificient ransom, to redeem him from lying unburied--a fate which seemed to the Trojans more terrible than death itself-jHecuba does all that she can to deter him from the noble effort. We learn. of course, from Homer of the subsequent fate of Hecuba. According to later writers she was Amade captive and slave by the Greeks after the fall of Troy.

Arete, wife of Alcinous, king of the Phaeacians, on the other hand, is a queen in the midst of peace and prosperity. She guides her household and settles disputes of her people,even the quarrels of men (2), being honored as no other woman in the world is honored by her husband. (3). Nausicaa and Athene both give to Odysseus the same advice(4), to apply for succour to the queen. If her favor is secured, the hero may be sure of his return to his native land. When Odysseus enters the palace he passes by the king and makes his appeal to Arete as she is sitting with her spinning, by her husband and her sons, near the fire in the midst of the counsellors of the Phaeacians. This was her usual place, clearly the place of honor in the hall. She recogntzes the clothing worn by Odysseus as the handiwork of her women, and discerns that he must have received aid from her daughter Nausicaa; but she discreetly awaits the departure of her guests before making inquiry
(1) $I I .24,747-59$
(2) $0 d .7,74$.
(3) 0d.7,
66-77. (4) Od.6, 3I0;
7.75. 
with regard to this.(1).

At the conclusion of Odysseus' story of the Fair Women whose shades he had seen in Hades, Arete is the first to break the silence, clai ming Odysseus her special guest, and suggesting that additional gifts be bestowed upon him.(2). The oldest counsellor of the Phaeacians takes up the proposition, and says that the queen's words are just what might be expected of her.(3). It is she, not the king, to whom Odysseus makes his formal adieu, (4), an It is she who sends women to bear to the ships the gifts that he has received from the Phaeacians.(5).

Of all the beautiful creations of Homer's genius, there is none, perhaps, so attractive, so charming, as the sweet, gentle, innocent, yet high-spirited and courageous Nausicaa. The dal ghter of Arete and the powereul and high-minded Alcinous-- an only dau ter with five brothers (6), petted but not "spoiled"----is one of the most attractive characters of the poems and is the only young damsel just reaching time of marriage, $(7)$, whom Homer depicts. In his Nausicaa, he gives us a perfect picture of the Greek maided in excelsis, in the springtide of her youth an d beauty.

Homer paints in glorious colors " the high-roofed hall of the great-hearted Alcinous", (8), and the great garden without the courtyard near the gate.(9).
(1) $07.7,238$
(2) $0 d .11,338$
(3) $0 d .11,344$
(4) Od. 13,57
(5) Od. 13,66
(6) $0 d .6,62$
(7) $0 d .6,27 ; 277$
( 8) 0d.7, 85-102
(9) $0 d .7,102-132$ 
In the most pleasing surroundings Nausicaa was reared under wise and affectionate parents, in comfort, and even splendor, rejolcing in the free life of the country, conscious of the favor and protection of the gods, whom she was accustomed to see as guests in her father's house. Nausica, plays a most important and decisive part in the life of Odysseus, a.s he in hers. She is employed by A thene to save him from impending death and to set him well on his way towards his longed-for home. Inorder to prepare the way for the kindly reception of Odysseus by the Phaeacians, on the night after he is cast on their shores, A thene visits Nausicaa in a dream and reminds her that the household linen should be washed, and that the time of her marriage is near, when she should not only be well-clad herself, but also furnish raiment to the groomsmen.(1). In the morning, Nausicaa goes to her royal father, whom she addresses as "papa dear" ( $\pi$ ' $\pi$ Ta $\phi i \lambda \in \quad(2)$, and asks for his wagon and mules that she mi ght go to theriver with her attendants and wash the clothes.. The maidens make a frolic and sport of their

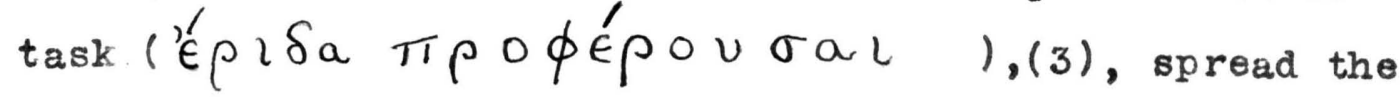
garments in the sun on the clean pebbles, end, while they wait for them to dry, they bathe and take luncheon, then play a game of ball. "And ever as Artemis, the archer, moveth down the mountain, either along the ridges of lofty Taygetus or Erymanthus, taking her pastime in the chase of boars and swift deer, and with her the wild
( 1) $0 d .6,26$
(2) $0 \mathrm{~d} \cdot 6,57$
(3) $0 \mathrm{~d} \cdot 6,92$ 
wood-nymphs disport them, the daughters of zeus, lord of the aegis, and Leto is glad at heart, while high over all she rears her head and brows, and easily may be known-but all are fair; even so the girl unwed outshone her maiden company".(1). At last a maiden fails to catch the ball which Nausicaa has tossed and it falls into an eddy of the river.(2). The maidens shriek and rouse the sleeping Odysseus, who appears from under the bushes like

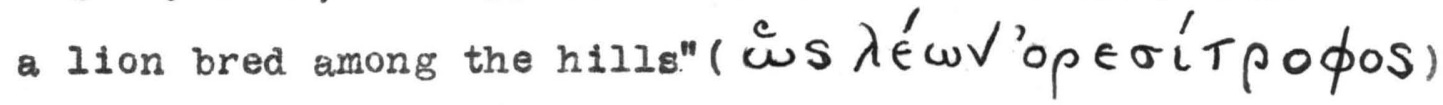
(3). The other maidens all flee, but Athene gives to Nausicar courage to remain.(4). Then the afflicted hero addresses her in a speech which is a very model of gallant, refined, and persuasive eloquence.(5). Nausicaa, touched by Odysseus' prayer-- as what woman would not be--does more than he has asked, bestowing on him raiment and food, and directions for reaching the palece and supplicating the queen. When Odysseus has bathed in the river, Athene makes him greater and more mighty to behold and sheds grace about his head and shoulders. "Then he walked apart along the shore and sat down, glowing in beauty and grace and the maid gazed upon him." (6).

We now see the first budding of love in her pure and as yet untroubled heart, which with true Homeric naiveté, she half-jokingly confesses to her companions: "Iisten, my white-armed maldens, and I shald tell you something: Not without the will of all the gods has this man come among the god-ike Phaeacians. Erewhile he seemed to me
(1) 0 d.6, $102-109$
(2) $0 d .6,110-117$
(3) $0 d .6,130$
$(4) 0 d, 6,141$
(5) $0 d .6,149-185$
(6) 0d.6,23\%. 
unseemly, but now he is like the gods that keep the wide heavens. Would that such a one might be called my husband dwelling here and content to stay! But come, my maidens, give the stranger meat and drink." (I).

Having arranged the clean linen in the wagon, (2), and mounted, she gives Odysseus directions to follow her to the palace of her father. With maidenly caution and reserve, she tells him to walk behind the wagon with her attendants as quickly as possible, as long as they were in the open fields. But when they arrived in the city, then he was to dit down in the grove of Athene, near the road; "for", she said, "I would aroid the ungracious speech of the baser sort of people and there are too many insolent folk who might meet me and say:' Who is this that goes with Nausicaa, this tall and goodly stranger? Where did she find him? Her husband het will be, her very own. Either she has taken in some shipwrecked wanderer of strange men, or some god has come in answer to her instant prayer. From heaven has he descended and will have her to wife forever--for, verily, she holds in no regard the Pha e $e_{1}^{a} i a n s$ here in the land, the many men and noble who are her wooers'. Thus will they speak and that would be a cause of reproach to me." (3).

Her very caution betrays the nascent incination of her heart; and the comments of the people which she imagines -..-that, after all, show high appreciation of her immeasurable superiority---imply that her heart, untouched
(1) $0 d .6,239-46$
(2) $0 d .6,251$
(3) od.6, 276-85 
\# by any of her noble countrymen, wes beating with a new sensation in favor of the goodly Odysseus.

We have dwelt at too great length, perhaps, on the appearance and actions of Odysseus, because of the love with which they have inspired the maiden heart of the lovely Nausicaa. We see, in the description of the banquet, how Iittle of the herolc there was in the characters of her voluptuous countrymen to warm the imagination and touch the heart of so pure and noble a girl as Nausicaa. We learn incidentally that she remal ned indifferent to the suit of the gay young Phaeacian nobles. But when Odysseus appears--the hero of a hundred battles, the bold mariner who has just emerged from long conflict with the angry sea-god-.-she falls in love with him at first sight. And the impression he made on her at their first strange meeting by the river-sice is deepened by all that she afterwan save of him, by his strength and manly beauty, his skill in games, his wondrous eloquence in the relation of his manifold suffering and trials.

Yet when she learns that he is married and must go and leave her to her dreams, there is no frantic outbreak of disappointed love. She lived in a contracted sphere, in simple patriarchal surroundings, but in that narrow world her being was harmoniously perfect. Like all Homeric women, her inclinations were restrained by the $a i \delta \omega^{\prime} s$, the self respecting modesty, of the Greeks, and the s ctity of family customs and traditions. She was no heroine in the modern sense of the word, but a noble, unsophisticated girl of sweet, cheerful, and amiable nat- 
35.

ure, without that depth of sentiment, that tearing violence of passion, in which modern romence delights. She was no Iphigenia or Antigone, no Dido, painted in blood red colors; and yet her image $i$ s stamped on our imaginations with the clearest lines, and the freshest, loveliest hues.

How characteristic is her farewell to Odysseus in its quiet simplicity, its modest self-restraint: As Odysseus feasts for the last time among the Phaeacian nobles, "then Nausicaa, dowered with beauty by the gods $(\theta \in \widehat{\omega} v$ ' of the well-built hall and marvelled at Odysseus, beholding him before her eyes; and she spoke and addressed to him winged words: 'F'arewell, stranger; see that thou rememberst me in thy country on a day, for that to me first thou owest the price of Iife'".(2).

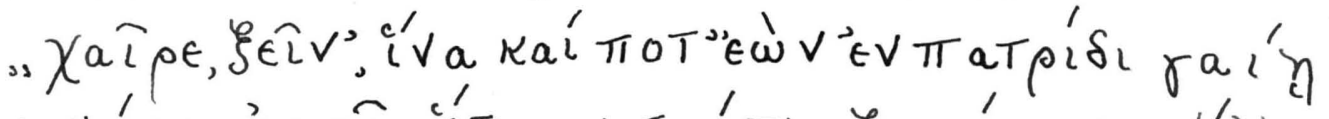

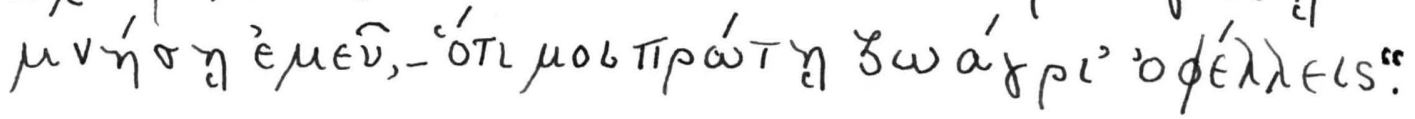
We cannot believe that his heart remained untouched by so much beauty and sweetness, and by such vital services in the hour of his greatest peril. And Odysseus of many counsels answered her saying: "Nausicaa, daughter of great hearted Alcinous, yea, ma zeus, the thunderer, the lord of Hera, grant me to reach my home and see the day of my returning; so would I, even there, do thee worship as to a god, a.l my days forevermore, for thou, lady, hast given me my Ilfe." (3). Yet Odysseus goes calmly to the royal (1) od, 8,457 (2) od, $8,46 I,(3)$ od, $8,464-8$. 
banquet; and Nausicaa looks after the retreating form of him who alone had touched her heart, and retires quietly a d sadiy to her chamber and we see no more of her. She is placid and resigned, but we wonder if she will be so merry again at ball and the dance, as before the meeting by the river.

As we contemplate the sweet image which Homer has drawn upon our hearta, we are astonished to remember how short a space she occupies in the beautiful Phaeacian episode. Yet it brings her before us not only in the clearest outlires, but with the brightest and fairest colors. She stands before us dowered with beauty by the gods, religious, (I), helpful and loving to her parents, kind and hospitable to strangers, brave and cheerful, freely joining in the dance and song with her companions, so virginal that even her dreams are not of lovers but of Iinen, (2), tho' keenly appreciative of heroic excellence, and capable of devoted love. Who can help loving this maiden? Who will not admire her dignified calmness under probably the bitterest disappointment that can befal a woman?

Clytaemnestra, Agamemnon's queen, has long been recognized as the Lady Macbeth of the Homeric poems; $;$ and yet, unlike her later English counterpart, she is the typical unfaithful wife. She is the special foil of Penelope, but the poet is far from painting her as wholly bad. He says expressly that she had a clear understanding (3), and that Aegisthus succeeded beyond all his expectations in persuading her to leave the home of her husband (7) Od.6. 187-90 (2) 0d.6,27 (3) 0d.3.266 
Agamemnon.(1). The Homeric story does not present her either as killing Agamemnon or as being killed by her son Orestes. Very probably the poet thot of her as committing sulcide in shame, on Orestes' return. But if she did not herself kill Agamemnon, she seems to have at least consented to it; for his ghost in Hades says that, "Aegisthus devised death and destruction for me, and with the aid of my accursed wife slew me," (2), and that clytaemnestra killed Cassandra by the sice of the dying Agamemnon and id not have the heart to close his mouth and eyes as he died, but departed and left him.(3). The contrast between the early and the later Clytaemnestra is so great that some scholars have thought the pictures to be inconsistent, but we need not suppose two forms of the stor. When she has once yielded to evil, the elements of good in her are turned to wickedness.

No doubt the fact that the captive women were often of noble and even royal lineage rendered the relations between them and their masters much more tolerable. These were, of course, the actual slaves of their masters. But personally they were on a level with the legitimate wives, and were therefore generally treated with kindness and consideration. We do not read of any instances of brutal violence inflicted on female slaves. Monstrous as it seems to us that women, both as wives and captives, should be subjected to the caprice of the "predominant partner", it is evident that they looked upon their position as quite in the natural order of things, and bore it with wonderful patience and resignation.

(1) $0 \mathrm{~d} .3 .275$ (2) $0 \mathrm{~d} \cdot 11,409-10$ (3) $0 \mathrm{~d} \cdot 11,422-26$ 
Briseis, a maiden of princely descent, and "like to golden Aphrodite" (I), is a striking instance of this. Achilles had slain her husband and her three brothers, and had taken her from home by force. Yet she is evidently attached to him; ard when the envoys of Agamemnon come to lead her away, their partinfi is a sad one; she goes with them " all unwilling", and Achilles"wept anon". (2). When Patroclus, the dear comrade of Achilles, is slain, Briseis mourns for him with the most affectionate regret, chiefly because he had promised to make her Achilles' wedded wife and prepare a wedding feast for her among the Myrmidones.(3). Even in Briseis we see the characteristic ai $\delta$ '́s. All that we hear of her feelings when she is torn away from the arms of Achilles is that she left him "unwillingly"; there were no shrieks, no hysterics. She was a woman accustomed to seeing herself disposed of by the arbitrary will and caprice of men.

Chryseis is another instance of a captive of war. When the Achaianslaid waste Thebes, she was carried off with all the other spoils, $(4)$, and in the division that followed she was given as a prize of honor to Agamemnon. Her father Chryses, priest of Apollo, came to the ships of the Achaians to ransom the fair cheeked maiden with countless gifts. But Agamemnon, " preferring her before Clytaemnestra his wedded wife, for in no wise was she inferior, neither in favor nor stature, nor wit nor skill" (5),

(1) II. 19,282 (2) II..I,346-9 (3) II.19,282-300.

(4) II.1,367 (5) II. II, 113-15. 
refused to exchange her for the ranso $\mathrm{m}, d$ in consequence brough t upon the Achatans the wrath of Arollo and countless woes. After ten days of plague and death,Agamemnon released her and she was returned to her aged father, the innocent cause of so much woe.(1).

A final exmple of typlcal Homeric women may be found In the clase of servants. Perhaps the most instructive exple of the position to which a slave might attain is that of the wise and thoughtful Eurycleia, the nurse of Telemachus, (2), and the trusted friend and confidan te of Odysseus and P elope. She was a woman of noble lineage, "the daughter of Ops who was the son of Peisenor" (3), whom Laertes, the father of Odysseus, had bought for twenty cattle while as yet she was in the pride of her youth.(4). Laertes had respected her, altho she was his bondwoman, "For he feared the wrath of his lady wife".(5). As a younger woman she had been the nurse of Odysseus, (6) later she became the loving attendant of Telemachus, and the trusted ruler of the house, to whom the other servants looked to assign them their several tasks. (7). She participated in all the joys and sorrows of the family, ad her advice and assistance are of the greatest value to her maste $r$ and mistress. She calls Penelope "my child" (8), w d Penelope calls her "dear little mother". To her (1).II. I, 446 (2) od. I,p435 (3)0d.20,149 (4) Od.1,429 (5) Od.1,433 (6) Od.19,482 (7) Od.2,346;20,148;22,395. (8) $0 d .23,5$. 
alone Telemachus confides the secret of the intended journey in search of his father.(1). It was she who first recognized Odysseus by the scar on his foot, which she was bathing, and, in spite of her excited joy, she faithfully kept the secret from Penelope.(2).

Yet there is no doubt of her servile condition and absolute dependence. When she comes to the upper chamber of her mistress, "laughing aloud to tell her that her dear lord was within, and her knees moved fast for joy, and her feet stumbled one over the other" (3), she finds Penelope asleep. On awaking, Penelope harshly chides her: "Go to now, get thee down and back to the women's chamber, for if any other of the maids of my house had come and brought me such tidings, and wakened me from sleep, straightway would I have sent her back right rudely to return within the women's chamber; but this time thine old age shall stand thee in good stead. "(4). The case of Eurycleia was, no doubt, and exceptional one, and slavery must have had its hardships and its inevitable demoralising effects. We know in our own acquaintances the counterpart of poor Hecabe, all mother, as fierce against the slayer of her darling Hector as a tigress against the huntsman who has robbed her of her cubs. (5). We kmow Andromache, the loving wife and tender mother, the sad, ill-fated spouse of the gallant patriot Hector. We have our faithful Penelppes
(1) Od.2,349--60
(2) $0 d .19,380,392,467$
(3) $0 d .23,1-3$
(4) Od. 23,20-24
(5)
I $1.24,212$ 
faithful during long absense to not too faithful husbands like Odysseus. We know, alas! our Helens, with beauty enough to set the world ablaze; whom, tho' we cannot altogether excuse, we are fain to love and pity. And above a11, we still have in many a home our true Nausicaas, our stately, peerless maidens, flresh, sweet, and innocent, joyous, brave and true.

Now let us consider Woman and her part in the great Latin epic, the Aeneid of Vergil. Here, as we should naturally expect from the general purpose and character of the poem, we do not find family life portrayed in detail or as intimately as in the Iliad and Odessey. In the Homeric poems woman plays a definite and important, as well as interesting, role, and she is ably represented in ten distinct types. In the Aeneid, on the other hand, woman is less portrayed and is of less moment to the general action of the narrative. Nowhere have we any accounts comparable to the scenes of domestic and family life of Arete's palace or Penelope's hall; no where pictured a Latin Nausicaa. In his story of national origin and development, Virgil, of course, found no place or need for relating marriage customs or for mentioning, even in an indirect way, the occupations and pleasures of women. His was a far different purpose,--to make a serious, conscious appeal to a nation, as we understand the word "nation" today," to a people of one blood living within welldefined bit broad limits, a people with various traditions all fusing in one common tradition" (I), and to establish the divine origin of his beloved Emperor Augustus. Virgil 
is more interested in the character of the people than in the mere details of everyday life. It is on this that he spends most care. He is a philosophic student of history, and he is tracing for us the emergence of the higher life of Italy from barbarism.

When we think of virgil in relation to Woman, Dido, the Phoenician queen, immediately comes to our minds, and so she should, being the greatest and most important feminine character in the Aeneid. Ovid tells us that no part of the Aeneid was so popular as the eplsode of Dido. (1). Macrobius says that for centuries, painters, sculpors, and workers in embroidery had turned to Dido, as if it were the only subject in which beauty was to be found, while the very actors had never ceased to tell her sorrows in dance and song. (2). Augustine himself confesses that he wept to read of Dido, and"how she slew herself for love", and he links her story with"ipsius umbra creusae".(3). And today there are still those who maintain that "what touch of human interest the Aeneid can claim it gains from the romance of Dido." (4). That Dido has ruined the chara cter of Aeneas with nine-tenths of his readers is the admission of one of Virgil's most sympathetic critics. (5)

It is wiser, perhaps, to turn from the impressions of Virgil's critics to the impression which the story must have left in the mind of Virgil himself. It is surely needless to assume that the first of poetic artists has

(1) Tristia,2,533 (2) Macrobius, Sat.5.17. 5-6

(3) Augustine, conf. I, $13.2 I(4) \mathrm{H}$ istory of Aesthet(ic, Bernard 
forgotten the very rudiments of his art, in placing at the opening of his song a figure that strips aII interest from his hero. Nor is it needful to believe that such a blunder has been unconscious, and that virgil has had to learn the troe effect of his episode on the general texture of his poem from the reader of today.

The poet who painted for us the character of Dido must have felt, before he could have painted it, that charm which has ever since bewitched the world. Every nerve in Virgil must have thrilled at the consummate beauty of this woman of his own creation, her self-abandonment, her love, her suffering, her despair. If he deliberately used her simply as a foil to the character of Aeneas, it was with a perception of this charm infinitely deeper and tenderer than ours. But he did not use her as a fo1l. Impulse, passion, the mighty energies of unbridled will, were wrought up into a figure of unequaled beauty, an $d$ then set against the true manhood of the founder and type of Rome, the manhood of duty, of self-sacrifice, of self-control.

To The stoicism of Virgil, steadied by a high sense of man's worth and work in the world, braced to patience and endurance for noble ends, passion---the revolt of the individual self against the world's order---seemed a light and trivial thing. He could feel and paint with exquisite delicacy and fire the charm of woman's utter love; but woman, with all her loveliness, wanted, to him, the grandeur of man's higher constancy to an unselfish purpose, varium et mutabile semper femina. 
Passion, on the other hand, is the mainspring of modern poetry, and it is difficult for us to realize the superior beakty of the calmer and vaster ideal of the poets of old. The figure of Dido, whirled hither and thither by the storms of warring emotions, reft even of her queenly dignity by the despair of her love, degraded by jealousyand disappointment to a very scold, is in marked contrast to the calm, serene figure of Aeneas.

It is Dido's position as a great woman and a queen that turns the erotic story into a tragedy; and the power of the piece lies largely in the fact that we sympathize with every move of Dido, but at the same time know that she cannot succeed. The coming of the Trojans could appear to her anly as a special providence, both for her and for the city, and $t$ her as the queen belonged the right to invite them into the kingdom and to offer the scepter to Aeneas. She showed a manlike energy in the work. From the moment that Aeneas appears, she determines his conduct. She plans the banquet, asks for the tale of Troy, and asks for it again and again. Once resolved upon the marriage, she sets about the wooing; she leads him thru the city, shows him the walls begun, and the sidonian wealth. She took his sword and gave him a Trojan sword in its place. She gave presents to Ascanius. She arranged the hunt, and, last of all, she dressed Aeneas in Tyrian fashion in garments woven by her own hands, and set him to superintending the building of her walls. It was partly this energy of hers that carried Aeneas away, and it is partly this that carries the reader away. The same 
vehemence that drove her madly on to reach the goal she had in view, swept her on to destruction. She was capable only of great things--great success, or awful ruin. What she sought for herself was for the best advantage of her city, an for herself she wanted no more than the world grants to a woman, and especially to a good woman and a queen. virgil would have us believe that it was against the inexpugnable piety of Aeneas that the imperious nature of Dido dashed itself in vain. Whether we are really convinced of this, or whether it seems rather that the heart of the hero was incapable of being equally moved with hers, we, at any rate, cannot help feeling that she deserved and had earned a great happiness to crown her life, but fate at the last moment cast her down.

Of the hero of tragedy, it is required that he be human like ourselves, but raised above us in rank and fortune, in powers and capacities.(1). All these requirements are eminently fulfilled by Dido. She is no less noble to in rank and birth than she is illustrious for power and character. She is the sister of a king and a queen herself, and has the queenliness of nature. She is, with all her power and force, a true woman, as the affection of all posterity has proved.

In the Aeneid Dido is claimed to be the daughter of Belus and the descendant of Agenor, from whom the famed Europa also traced her Iineage. The story ran that Jupiter loved Europa and carried her off to crete, where she became the mother of Minos. Minos was the husband of the unhappy Pasiphae, sister of Aeetes and Circe, and of 


$$
46 .
$$

Pasiphae were born the two victims of unhappy love, Arladne and Phaedra. Virgil's heroine belongs, therefore, by right of birth, to the company in which she wanders in the underworld (I), and to the great family whose women seem condemned by destiny to forbicien or hopeless love. She will be also kindred of the daughters of Danaus, who were of the line of Belus and Agenor, and the Danaids, too, were famous among victims of unhappy Iove.

If Dido has the claims of a famous origin, she possesser queenly beauty, too, and all the accessories of royalty. She was most beautiful in form; she bore herself like Diana, and had the stature of a goddess. She was surrounded with all the signs of rank. Her progress to the temple was in royal state. The magnificence of the banquet hall reminds us strongly that she was a queen, while we feel no less that Aeneas is a pririce among men. Passing to the day of the hunt, we have the glittering cavalcades, the impatient horse caparisoned in purple and gold, and Dido, with all her retinue, clad in the embroidered sidonian habit; her quiver is of gold, her hair is bound up in gold, and the golden brooch fastens her scarlet cloak. Gofd is here mentioned three times in two Iines, and five times in fourteen; 2 ); for the glitter of metal and color we should have to go to Pindar for a parallel.(3).

But even if we omit the claims of birth, and omit all the pageantry of the court, Dido is still a queen. She has power. Men and women obey her. Anna is her slave.
( I) $A . \underline{6}, 4.42$ sq.
(2) $\mathrm{A} .4,129 \mathrm{sq}$.
(3) 01ympiad I. 
The nurse went to do her bidding with aged haste. Dido had been in sorrow and in danger and had conquered them. She knew how to rule and did not shrink from the severest measures; her soldlers had orders to burn and kill. She defied her enemles and scorned her suitors. Moreover, she had a queenly pride-pride that had a touch of egoism in it. The hero of tragedy may well be consclous of his greatness as Dido was. She speaks of the city that I am founding(1). In her dying speech there are no words so pathetic in contrast to her situation as the proud lines:

et nunc magna mei sub terras ibit imago. urbem praeclaram statui, mea moenia vidi, ulta virum poenas inimico a fratre recepi.(2). Ther $e$ is something pitiful in the use of mei for mea, and in the first person of the perfects, recepi, statui, vidi. The world loves a true queen all the more for her pride, and a touch of egoism is only the perfection of pride. Dido's name is mentioned for the second time in the Aeneid side by sice with the proudest word in the Latin language:

Imperium Dido, Tyria regit urbe profecta germanum fugiens.(3).

The "dux femina" (4), of the same passage became a classic, an d recurred to the mind of Tacitus when he wrote of the British warrior queen, Boudicea.(5). The word "regina" in
(1) A. 1,573
(2) $A .4,654-6$
(3) A. I, 340
(4) A. I, 364

Agricola, 16, 1; 31, 5 . 
Iatin carried with it only ideas of power and magnificence and was wholly free from the sinister connotation of the masculine "rex". Virgil insists upom calling her by this name, and it shares an ugly frequency with the oft-recurring "infelix Dido." In these two designations is contained the whole tragedy, the pitiful and awful contrast between her fortune and her fate.

But exalted as Dido is by royal eminence and by 1llustrious birth, the woman is not lost in the queen, and she remains to the end intensely human. The great and immediate success of the Aeneid and the preference that antiquity felt for the Dido episode, as well as it's poplilarity to the present day, are the best evidences that she was a true woman, yet certain feminine traits may be painted out as conspicuous in her portraiture. She cast down her eyes with shame as she excused to Ilioneus her cruel treatment of strangers. She contended with rising tears when love struggled with her cherished resolution never to ma rry. It was a feminine way of hers to keep the cavalcade waiting on the day of the hunt, and it was like a woman to swoon away after loading Aeneas with reproaches. We percelve her womanhood most, however, in the love she lavishes upon the little Ascanius, and it is from a childIess woman's heart that the words come:

saltem siqua mihi de te suscepta fuisset an te fugam suboles, siquis minl parvolus aula Iuderet Aeneas, qui te tamen ore referret, non equidem omnino capta ac deserta viderer.(I)

(1) $A \cdot 4,327-330$ 
Dido was preeminently a person of action. She assumed a man's role in life and played it well. She acted with decision against her husband's murderer, she led a migrating people, and founded a city. It is evident how the action of the so-called plot from her first appearance moves at her initiative, and how, before her masterful and imperious nature, even the greatness of the hero bave way for a time. But power of action does not usually go with power of reflection, and this is so with Dido. Her energy and her passion usurp her nature. Her strongest capacities are for pride, a womanly quality, end revenge and love. Doubt is an agony to her. Decision restores her to herself. She gapes breathless over the steaming entrails of the victims. Whether she read them aright or not we are not told, but, at any rate, once done with them, she set about winning Aeneas as people of action usually do. Once she resolved to die, the way and the means were soon found and the preparations made. Her violent death was a fit close to her Iife.

Yet there is another side. It seems strange that we should be told that Barce was the nurse of Sychaeus and that Dido's own had died in her former home.(I). It may have been so in the legend, but this could hardly justify the mention of it at a moment when our feelings are so completely absorbed in the fate of the heroine. It must be felt to contribute in some way to the tragic effect at which Virgil aimed, and, if so, it may be intended to sug; lest to us the utter loneliness of Dido's position. She hasno (I) A.4, 633 
50.

confidant. All her own had been taken from her. Dido is absolutely alone. Her father is dead and her mother is not ever mentioned. Her sister Anna is under the spell of the queen's superior force and is not capable of going far with her sympathy. There is no Tyrian in her company who might aspire to her hand; all her suitors were either left behind or were barbarians. The men of her own race are nameless, except the old bard Iopas and the sot Bitias, who drank the great bowl of wine at one draught. There is no counsellor on whom she may lean. In the first book she is pictured as an absolute sovereign, giving laws and work to her subjects. She speaks to IIloneus of Carthage as "the city that I am founding", and on her funeral pyre she said "I have founded a great city, I have seen my own walls." To herself, ax to Venus, she is the "dux femina facti."No laudatio funebris could be more eloquent than the two Iines of Anna's lament,

extinxti te meque, soror, populumque patresque Sidinios urbemque tuam. (I).

Carthage was her city. She had no partner in her deed, and it might well be feared that with her the city, the people and the fathers would pass into nothingness. Virgil tells us much by his șilence, and none knew better what could be as well suggested as told. Dido was haunted by her ow isolation. With foes around her, and a threatening enemy at home hating her with the hate of a brother, and that towards one whom he had wronged, she felt a fear that she would acknowledge to none, and scarcely to herself. Aeneas 
seemed to have been specially sent by heaven to be her stay and to ensure the continuance of her city. He could do what she had never hoped, make her hapry and rescue her from her dread. When he was about to go, her old fears returned.

Diob was a leader of men and became a type for great women. The words, "dux femina", fastened themselves in the mind of Tacitus as we have already said, and twice he uses them to describe the British warrior queen, Boudicea. In later times, Zenobia would have herself to be of the same Ineage as Dido, and imitated her in her dress.(I). Iike these great women, Dido stood alone and was overmastered by fate. If Aeneas was hounded by the spite of a goddess, he had also a goddess to protect him. But the friend of Aeneas and the foe alike were indifferent to Dido, thru their machinations her fair name, her happiness, and her life were ruined. She was able to master human foes, but with the gods no mortal can contend. At least one critic has looked for the tragic flaw or frailty in Dido's character and it is not far to see k. Dido fell as any woman may fall. As a woman she was specially tempted. Advantage and love drove her irresistibly in the same difrection, but even then she might have endured had no Juno plansed the unlucky storm.

Dido had been intensely proud, not only with the pride of the great that have the power to achieve and know it, but also with a pride that was absolute and uncompromising. She could not, like Penelope, play for time with suitors

(1) Trebellius Pollio, Tyranni Triginta,27,1; 30,2: 


\section{2.}

whom she intended to reject. She rejected the Libyans in. a way that made them enemies. She preferred to stand alone before them rather than to delude them. Her nature was brave, and, as brave natures usually are, it was simple. Hers was a character so rare and so honest d intense that there was no man in all the world that was fit to be her lord and he could not be hers. Thus both her nature and her lot were lonely. Iido is truly a tragic heroine. In power and energy she reminds us of clytaemnestra and Medea. Her suffering is equal to that of Orestes or Pentheus. Only in tragedy did ancient literature know women of that type. Homer gives us good but passive women Iike Penelope, Andromache and Nausicaa. Dido was as proud and imperial as the greatest queen of the tragic stage. We may conclude by calling attention to the exquisite bit of occult lore with which the fourth book ends.(I). These lines are like an elegy over the departed queen and seem to contain the final reflections of the poet upon her Iife. We are told that this was broken off in the riddle, that she died not by fate but unhappy and before her day-nam quia nec fato merita nec morte peribat, sed misera ante diem subitoque accensa furore.(2). Her death was not in keeping with her merits and her end was due to a madress.

The sister of the heroine is a familiar figure in Greek tragedy. Ismene, in the play of sophocles, takes a lower and less reflective view of duty than Antigone, and is quite unable to grasp what it is that moves her sister 
to action. So in the Aeneid, Anna, the sister of Dido, represents a more commonplace type of mind. She is shrewd enough. Probably long before Dido got as far as "Anna fatebor en im" Anna had summed up the situation, and by the time the curse and the tears ended the speech she knew quite well what her own line would be. Anna is a woman of the common-sense school, not at all of an imaginative habit. To prove this, it is only necessary to anticipate by a Iittle the moment when Dido has res olved to kill herself. Of such an outcome Anna never dreams for an instant--non tamen Arna novis praetexere funera sacris germanam credit nec tantos mente furores concipit aut graviora timet quam morte sychaei.(1). Such is Anna's view, and it is rather lacking in sentiment. But it is hardly more so than her first speech to Dido on the subject of her new passion.(2).

It is a most significant utterance. Why, she asks, should Dido forego the pleasures of husband and children? She has remained unmarried so far out of loyalty to sychaeus.

id cinerem aut manes credis curare sepultos?(3) To Anna, Sychaeus

$$
\begin{aligned}
& \text { "Was allve and is dead; } \\
& \text { There's no more to be said." }
\end{aligned}
$$

Anna asks herself why Dido has never married again, and the only reason of which she can conceive - the only reason that could weigh with herself--is that she had not so (I) A.4,500-2 (2) A.4,3I-53 (3) A.4,34. 
far wished to do it. But if she wishes to now, why should she not? Iarbas and the African princes she might well dislike for their complexion; but Aeneas is a hero of another color; and if Dido cares to marry him--

placitone etiam pugnabis amori?(I).

Anna is a Cyrenaic in her philosophy and inclination is her guide in Iife. She proceeds to fortify her advice by a number of political considerations--

nec venit in mentem, quorum consederis arvis?(2) Gaetulians, Numidians, Barcaeans, and Tyrians are all threatening Dido, and only to be overcome by the aid of Aeneas.

Lavinia, only descendant of Latinus, king of Laurentum, is probably a fair example of the maidens of her time and station in life. She is rather a colorless sort of character, and is known in literature, if at all, simply because she becomes the wife of our hero Aeneas. She has undoubtedly been reared in simple, patriarchal surroundings, under the careful directions of her parents. Like Nausicaa, she is

iam matura viro, iam plenis nubilis annis;

multi illam magno e latio totaque petebant Ausonia; (3);

On the other hand, Lavinia seems to have had very little to say in the choice of her future lord, for petit an te alios pulcherrimus omnis Turmus, avis atavisque potens, quem regia coniunx adiungi generum miro properabat amore.(4).
( I) A. 4,38
(2) A. 4,39
(3) A. 7, 53-55
(4) A. 7, 55-57 
While as for her father-

nec purpura regem

picta movet, nec sceptra movent Priameia tantum

quatum in conubio natae thal amoque moratur;(I);

and finally, obeying the oracle, (2), hel broke all bonds an parted the maiden from her promised husband." (3). We are sorry for poor Iavinia in that she is "causa mali tanti" (4), yet often we forget her part in the narrative. It was for her sake that Aeneas contended mightily against Tumus; and Aeneas being victorious, Lavinia became the mother of the glorious and far celebrated "populi Romani". Creusa, daughter of Priam and Hecuba and the Trojan wife of Aeneas, is another of the less eminent characters of the Aeneid. We see her at the time when Troy has just been surprised by the Greeks, as she bewailed their sorry plight and urged Aeneas to save his father, son, and wife. sin aliquam expertus sumptis spem ponis in armis, hanc primum tutare domum. Cui parrus Iulus, cui pater et coniunx quondam tua dicta relinquor?(5) As they fled thru the night, Aeneas carrying his aged father and leading little Ascanius by the hand, in the confusion Creusa was separated from her dear ones, nor was her absence observed until the other fugitives arrived at the mound appointed for assembling. Entrusting Anchises and Ascanius to his companions, Aeneas reentered the burning city in quest of his wife; but while he was seeking her in every quarter of Troy, Creusa appeared to him as a deified personage, and appeased his alarm by telling him
(1) A. 7,251-3
(2) A. 7, 96-101
(3)
A. $12,30,31$
(4) A. II, 480
(5) $A, 2,676-8$ 
that she had been adopted by Cybele among her own attendant nymphs. She then urged him to pursue his course to Italy, with an intination of the good fortune that awaited him in that land.(1).

Another of the daughters of Priam and Hecuba who plays a minor part is Cassandra. She was beloved by Apollo and promised to listen to his addresses, provided he would grant her the knowledge of futurity. This knowledge she obtained, but as she was regardiess of her promise, Ap0110, in revenge, determined that no credit should ever be attached to her predictions.(2). Hence her wamings respecting the downfall of Troy and the subsequent misfortunes of the race were disregarded by her countrymen. (3). When Troy was taken, she fled for protection to the Temple of A thene, but was there exposed to the brutality of Aiax, the son of 0ileus.(4). In the division of the spoils, Cassandra fell to the share of Agamemnon, and on his return to Mycenae, she was murdered beside him by his wife clataemnestra.

In the Aeneid we see again the gentle Andromache, still lamenting for her dear lord Hector and her own Astyanax. After the destruction of Troy she was carried off by Pyrrhus to Greece and there was married to Helenus, one of her own people, and now king of Epirus.(5). As Aeneas approached the town of Buthrotum, haply he came upon Andromache "in a grove before the town where she was
( I) A.2 ,562-794
(2) A.2,246-7
(3) A. 3, $183-87$
(4)A.2, 403-06.
(5)A.3,294-97 
making oblation of ritual feasts and gifts of sorrow to Hector's ashes and calling on his spirit beside an empty mound of green turf with two altars that she had hollowed out for a place of weeping." She related to Aeneas her fortunes since the fall of Troy, and inquired of him concerning the welffare of Ascanius.(1). After a pleasant visit, Aeneas and his comrades went ontheir way; and at their departure, Andromache "sad at thislast parting brings figured raiment with woof of gold and Phrygian scarf for Ascanius, and falls not short in courtesy, loading him with gifts from the loom. 'Take these too,'she says, 'my child, to be memorials to thee of my hands, and testify long hence the love of Andromache, wife of He ctor. Ture these last gifts of thy kinsfolk, 0 sole surviving likeness to me of my own Astyanax! Such was he, in eyes and hands and features; and now his equal age were growing into manhood like thine."(2). Virgil did well in reproducing Andromache as the same sweet gentle mother of Astyanax as portrayed by Homer.

If Homer has portrayed in the Illad and Odyssey eternal types of Woman, so also has virgil given us an eternal type in the tragic episode of queen Dido. In her powers and energies, she reminds us of Clytaemnestra, but how far different is she from Andromache and Penelope. Passion consumes Dido. She knows not the aij '́s which characterized the Homeric women in the hours of their deepest sorrows. It is difficult indeed to imagine 
Nausicaa committing sulcide because of her disappointed love for Odysseus; equally difficult, if not impossible, to picture Dido bidding Aeneas a passive adieu. The difference lies in the intborn natures of the two. So, too, we wonder if any of Homer's fal $r$ women could have founded $a$ city and beheld her own walls as did the mighty carthafginian queen. Penelope, Andromache, Helen, and Nausicaa are a.l blessed with a passiveness, a resignation to fate and the will of the gods that Dido utterly lacks, nay, she even flies in the very face of divine opposition. Dido, we have seen, is a woman of some character and greatness, but her forte is action rather than reflection. Hers after all has been an "unexamined Iife", and, in her hour of greatest need, she has nothing adequate on which to fall back. She surrenders at once, and gives up her ideal for her inclination.

No where in either the Iliad or the Odyssey do we find a woman comparable to Anna. She is a stock character of tragedy, andas such, she fulfils her requirements in the tragic story of her sister. We need only recall the Antigone of sophocles, for exmple, to bring before us a sister occupying a place very similar to that of Anna. The more conventional minds of Anna and Ismene serve the purpose of making the isolation and the strength of the heroine stand out in clear relief.

Although Virgil has omitted a vast amount of intimate detail in which Homer seems to delight, we can not say that we feel the lack of it. The action and the progress 
of the Virgilian epic moves so rapidiy and holds our attention to such an extent, that we do not even think of the lesser items of interest. In the Homeric epics, where the women play important roles all thru the narrative which is less condensed than Virgil's, we expect to find mention made of the smaller things of their lives. Somehow we cannot but help but feel that Homer was intimately acquainted with such fair women as he pictures, but that Virgil's personal knowledge of womankind was rather limited To the writer of this paper, Virgil seems to have moulded Dido from the cold, lifeless clay with an unsymathetic mind, yet with an infinite genius and skill has produced a woman that is decidedly human, and one that demands and holds our interest, admiration and our sympathy.

Dante's life and his work are not to be regarded apart; they form a single whole, and they possess a dramatic development of unparalleled consistency and unity. The course of the events of his life shaped itself in accorda ce with an ideal of the imagination, and to this ideal his works correspond. His first writing, in his poems of love, and in the story of the New Life, forms as it were the first act of a drama which proceeds from act to act in its presentation of his life, with just proportion and due sequence, to its climax and final scene in the last words of the Divine Comedy. It is as if Fate had foreordained the dramatic unity of his life, and work, and impressing her decree upon his imagination, had made him her more or less conscious instrument in its fulfillment.

Date was a most mysterious person, and all that he tells us about himself is mystical and full of secrecy. 
His soul always walks, as it were, on unearthly paths beside his body. He was a man whose inward life was richer and more intense than that of other men, who very soon lifted himself from the platform of ordinary life to a higher sphere, carrying up with him whatever he touched; in his writings he gave the most detailed descriptions, not of his outward destinies, but of this higher iffe of his soul; an autobiography of his inward development, not of his personal history on earth; and just because he chose to throw so much light on what passed within him, and so little on his destinies in this world, we must renounce all hope of ever attaining a full knowledge of the latter. The same must be said of the woman whom he loved and made famous as none was made before her. Beatrice is the most enigmatic creature of all literature. Among the many women made immortal by the poets who loved them, she was exalted to such a height that the dazzling light which the poet shed around her hides her from our glances. "All his poetry was for her; his love for her was the golden thread, which now for a time deserted, again firmly grasped, seems drawn across the labyrinth of his Iife." (I).

"There is no great poetry without symbolism. The purer a poet receives life, and the fuller it falls in his soul's mirror, the richer in meaning will his work be." (2). We need not force more symbolism into Dante's poetry than it contains, and we shall find it but the more strikingly beautiful and mysterious for its being natural and clear. The real woman that Beatrice was appeared to him as something so high and as a reflection of something higher

( I) "Dante and His Time", Karl Federn, p.205. (2) ibid.226 
still, just as he expressed it in the Divine comedy, where she looks into the face of God and Dante into hers to catch the reflection of Divine Love, which in itself would be unbearable to him. She seemed to be the sweetest thing that God could create, a thing of heavenly nature that had retumed to its source, a lovely wonder, a "novem", a "nine" whose root is the "three", that is, the Holy Trinity, and she is a thing that the Holy Trinity created, in the loving pupose to make mankind blessed by her presence. As a painter chooses the fairest and noblest woman he knows to sit for a picture of the Blessed Virgin, so Dan te chose the fairst and noblest woman he knew to become the symbol of Divine Love and Grace.

She was to him an emanation from heaven, a concentration of all that is beautiful; she must of necessity become a symbol of the highest that he knew. A common mind would have invented some ideal woman for his allegory; that is the common way. But Dante chose a living women whom he glorified. Here as ever he dared to draw from life. He did not invent some female figure to embody a divine meaning, he saw the divine meaning embodied in the living woman. And when she died and became a spirit, the idea was rendered still easier. For now that she was a spirit, dwelling in the invisible world, and the corporal gament was put off, he had but to heighten her rank, not to change her substance.

It was Beatrice to whom, long years after her actual death, he became indebted for all the glories he was called 
upon to see. It was the spirit of his half-porgotten love who, out of pity for Dante, lost in the dark wood of Iife, sent Virgil's shade to his rescue. It was at her bidding that Virgil led him thru Hell, where he was shown the souls: In pain; then ovee the mountain of Purgatory up to the Garden of Eden. In Eden, Beatrice receives him with reproachful love and with him ascends thru the nine heavens to the Empyrean, where, like an immense white glowing rose, the celestial Paradise unfolds itself, and where, around the Holy Trinity, around God himself, the spirits of the blessed are sitting, and the angels are flying from leaf to leaf like golden bees. Here Beatrice, too, has her place in the inmost row on the fourth seat; the first is St. Mary's, the second Eve's, the third Rachael's, the fourth is Beatrice's; in the opposite row, among the sainted men, John the Baptist has the first place, facing that of the Virgin; on the fourth, corresponding to Beatrice's, sits St. Augustine.(I).

The Mirdle Ages more than any other were the times of allegory and symbolism. No better example of this could be found than in the procession of the triumphant church in the terrestrial Paradise.(2). The Gryphon, whose wings reach into heaven, is Christ, indicating His double nature; the car, drawn by Him, is His Church, and on His car stads, veiled, in regl attitude, Beatrice.

Beatrice standing on the car that represents the Church, must be the Iiving essence of the Church; so much is clear. Scholars do not agree on a more precise defini(1)Paradiso, XXX. \& XXXI. (2).Purgatorio,XXIX. 
tion. Some maintain that she stands for Theology, others propose Revelation, Efficient Grace, Inspiration, Beliei, and the like; all of which notions were sharply defined in mediaeval theology. To us, however, who cannot treat such conceptions as concrete and clearly defined things, who are not realists in the sense of mediaeval philosophy, to us all these seem, as it were, to melt into each other like clouds, without clear limits or contents. It is sufficient to say, Beatrice in the Divine comedy indicates the Highest that Dante knew, the essential spirit of the Christian Church as he saw, the highest illumination that Divine Grace concedes to mankind.

In the last part of the "New Iife" he tells of his infidelity to Beatrice, in yielding himself to the attraction of a compassionate lady in whose sight he found consolation. Again, in the "Convito",y Dante tells us that the compassionate lady was no living person, but was the image of Philosophy, in whose teaching he found comfort, not any earthly lady, but the lady of the understanding, the most noble and beautiful Philosophy, the daughter of God. And as this image of Philosophy, as the fairest of women, whose eyes and whose smile reveal the joys of Paradise, gradually took clear form, it coalesced with the image of Beatrice herself, she who on earth had been the type to her lover of the beauty of eternal things, and who had revealed to him the creator in his creature. But now having become one of the blessed in heaven, with a spiritual beauty transcending all earthly charm, she was 
no longer merely a type of heavenly things, but herself the guide to the knowledge of them, and the divinely commissioned revealer of the wisdom of God. She, looking on the face of God, reflected its light upon him who loved her. She was one with Divine Philosophy, and as such she appears, in living form, in the Divine comedy, a d discloses to her lover the truth which is the native desire of the soul, and in the attainment of which is beatitude.

Thus the vision of truth is the structural idea of Paradise. "Its glory is the splendor of truth, its progress is the enlarging perception of truth, and its blessedness is the ardent love inflamed by truth." (1). By a poetic conception of peerless beauty Dante measures his ascent, not by conscious motion, but by the radiance on the face of Beatrice. From the very first her glory dazzled his eyes; as they mounted upward she irradiated him with a smile such as would make a man in the fire happy, and finally her beauty became so intolerable that dh e dared not smile lest his sigh $t$ be shattered as a bough by the Iight pning.

Unless we can regard Beatrice both as a real person and also as an allegory, we shall not have placed ourselves at Dante's point of view. Beatrice, tho' taken as the type of Divine science, is recognised by Dante as the Beatrice Portinari who first stirred his soul to love and who died at the age of twenty-four, leaving for his eyes "the ten yearls'thirst." This mixture of symbolism with (1)Aids to the Study of Dante, C.A.Dinsmore, p. 344 . 
reality renders Beatrice frigid as a person. As soon as we have learned to sympathize with her humanity something always occurs to remind us that she is an abstraction. It is right and proper that mere human science should be excluded from Paradise and denied the sight of Beatrice.

A confusion of the person and the symbol impairs the charm of Beatrice. In the "New Iife", she interests us as a beautiful meiden, the youngest of the angels." In Purgatorio,(1), she revives this interest. But when she begins the sermon against Dante's sins, or when she is explaining the spots on the moon and smiling in sublime contempt of Dante's moral grossness, our interest is considerably refrigerated. She stands before us, in spite of the poet's pains, as a pretentious preacher or a stiff automaton-pretentious if we still regard her as a woman, stiff and cold if we accomodate our minds to the allegory. of this we can be certain, that Beatrice in the Divine Comedy is a symbol. Dante did love a real woman, and that woman was Beatrice, was the light of heaven itself. And the Beatrice of the Divine comedy is no other than the beloved of his youth. Dante certal nly never doubted for a moment that Virgil, who in the sacred epic stands for human wisdom or the like, once lived as a real Roman poet; he was sure that leah and Rachel, who in his poem symbolise active and contemplative life, were once living girls in Judaea of old; he himself in the comedy represents man in general, and jet was Dan te Alighieri the Florentine poet. 
Even so, Beatrice was at the same time the Florentine girl he had loved in early days, and the symbol of divine love in Heaven. In his works we can trace all the steps and phases of her glorification. At first she was but an earth-born woman he loved, but the world is full of symbols an d symbolism, and all poetry is based on this fact. The more poetical a man's soul is, the better is he enabled to see it. And such was the so ul of Dante.

We feel somehow that Homer was interested in the women he portrayed primarily because they were human; that Virgil's interest in Dido was purely objective; but we know that Beatrice was real to Dante, a living woman whom he had loved in his youth and later idealized and made the personification of Divine Science, of Love Superior. When we consider Woman--her position and the pert she played in the Divine Comedy--we begin and end with Beatrice. Comparing her with Penelope, Helen, or Nausicaa reminds us of the Apostle Pul's comparison of $\sigma a ́ p \xi$ (flesh) and $\pi v \in \hat{U}$ $\mu a$ (spirit) in his letter to the church at Rome. Homer's women are real, they have their counterparts among our own acquaintances; Dido and Anna are not unknown to our experiences. But who can say that he knows a Beatrice? Possibly some adoring young lover, but even he, alas! will be digillusioned ere long. Although there was once a real, living Beatrice, as we find her portrayed in the Divine Comedy, sh e has long since far transcended this sorry earth of strife and turmoll, has left our world, and Helen's, nd Dido's and sits among the celestial few in the awful presence of Divine Power. 


$$
67 .
$$

In the Homeric epics wom play a recognised role, yet even so she forms the background for the valorous deeds of Ares-ioving $\mathrm{Mm}$. In the Aeneid the Dido story is bot a single episale. For Dante and his Divine Comedy, Beatrice is ald.His beloved is for him the destroyer of all evil and the queen of all virtue. The influence of her beauty is such that he strives to clothe himself with noble thote, love, and filth. When human weakness almost overpowers him, it is her image that awakens him and recalls him wh he has already gone astray. Her image gives him new strength when he is on the point of letting his courage fail or is growing weary and shrinking from danger. For her sake he turned his back on the common herd and fled from their pastures; she became his guide to Heaven, even to God himself, and when he thot on her, he beheld the realm of the blest to which he was able partly to raise himself, paty felt himself raised. When in later years he looked back upon the period of his life that seemed to him like a lost Paradise, then di d the beautiful countenanee keep him upright, then did the eyes of his beloved in all the beauty of youth lead $\mathrm{hi} \mathrm{m}$ on the straight road. Then di d he learn from his yearning for her to love God, the highest good beyond which no man may alm.

A prerogative place among the great epics of the wor Id has sometimes been claimed for Paradise Lost, on the fround that the theme it handles is vaster and of a more universal human interest than any handled by Milton's predecessors. It concerns itself with the fortunes, 
not of a city or an empire, but of the whole human race, and with that particular event in the history of the race which has moulded all its destinies. Around this event, the plucking of an apple, are arranged, according to the strictest rules of the ancient epic, the histories of Heaven and Earth and Hell. The scene of the action is Universal space . The time represented is Eternity. The characters are God and all $\mathrm{His}$ Creatures. And all these are exhibited in the clearest and most inevitable relation with the main event, so that there is not an incident, hardy a line of the poem, but leads backwards or forwards to those central lines in the Ninth Book:

"So saying, her rash hand in evil hour Forth reaching to the ruit, she plucked, she eat. Earth felt the wound, and Nature from her seat, Sighing thro' all her works, gave signs of woe That all was lost." (I). From this point radiates a plot so immense in scope that the history of the world from the first preaching of the Gospel to the Millennium occupies only $s$ me fifty lines of Milton's epilogue.

Ben Johnson sald that Milton "knew human nature only in the gross, and had never studied the shades of character nor the combinations of concurring or the perplexities of contending passions." so in his epic, Milton treated nothing less momentous than the fortunes of the race. It is

\section{(1) Paradise Lost 9, 780-84}


probably from this cause that the incomparable grandeur of Milton's characters and situations springs. The conversations that he recoris are like international parleyings. Adam walks forth to meet the angel Raphael in ambass adorial dignity, the accrediter representative of the human race.(1). Eve is the official Mother of mankind. The question of Woman and her part in Paradise Lost is answered in the study of Fve, our common Mother. We feel toward her somewhat as we did in respect to Beatricethat she is a fragile sort of celestial being concerning whom we have little earthly experience. And yet, for all this feeling, we know that it was her frailty, her yielding to the temptation of satan, that drove the newlycreated progenitors of mankind from the Happy Garden. On Eve al one depends the plot of Paradise Lost. Her rash act of plucking and eating the frutt of the Tree of Knowledge is the focus toward which every line of the entire epic points, both forward and backward. In none of the other world eples does the single act of one woman have so great moment, not even in the case of Helen, as her elopement with Paris affected only a small number of people as compared with the destinies of a whole race. As Milton first introduces Eve to our view, we are at once impressed by the fact that she is entirely femirine, for in a few touches he brings out distinctly befo re us the soft, delicate, and loving traits in Eve, the (1) Paradise Lost 5, 350-7 
perfect woman. What better picture of her could one desire than that in which Eve herself relates of her earliest memories.(I). The coming into life as am awakening from unconscious sleep amidst the glory of Paradise (for, unlike Adam, she was formed in the Garden), the fearless wonder about everything and especially herself, the being attracted by a murmuring sound of waters, the beholding of her own beautiful form in the placid lake, the gradual transition into a state of love and desire for someone upon whom to lavish her affections, so that the NarcissusIike longing would have fixed her there forever had not a reality waited to satisfy it--these are the constituent parts of the matchless picture of the first woman.

But when brought into the presence of her future lord she does not at once submit; woman-Iike she must be wooed or never won. The passage (2) shows not more her loveIiness and grace than her entire womanliness; and the two are presented as a perfect pair of lovers, not as dull abstractions. Iife and joy a d love pulsate in every lineunclouded life, unmeasured joy, love unalloyed. Here, at least, Milton manifests none of that cold intellectuality which has been charged against him; and no more enchanting picture of wedded love has ever been presented than this framed amid the beauties of Paradise.

Again Milton gives us a picture of the happy pair which shows well the feminine traits of "our general mother" (3). It is late in the afternoon, and the signs
(I)P.I. 4, 449-75
(2) $\mathrm{P} . I_{1} \cdot 4,475-502$
(3) P.I. 4, 492 
of approaching night were one by or appearing. The slanting beams of the sun were gilding the inner side of the eastem gate of Paradise, but soon the blazing orb sank out of sight. Twilight and silence, companioss of Evening, moved over the landscape, than came the bright procession of stars, and at length the Moon, from among the clouds, "Apparent queen unveiled her peerless light, And o'er the dark her silver mantle threw." (I). Adam and Eve witnessed its glorious changes, both with gladness; but Adam, more prosaically, was reminded of his duties, while Eve, dreamy and imaginative, was wrapped in the poetic fancies and meditations stimulated by her surroundings.

A glorious morning led on a long-to-be-remembered day of Paradise. The spirit of evil had entered, but was driven away, and over the beautiful landscape no trace of his presence remined. But his visit was not without effect. The unquiet rest, the tresses discomposed, the glowing cheek and startled eye of Eve gave evidence of his malign work. The spiritual venom infused by the loathsome reptile thru the ear of Eve, while it did not make her guilty, yet prepared the way for a future temptation, created a sort of sympathy with evil and an attraction towards it. On the day of the Fall, it unconsciously drew her away from Adam, her safety, towards the serpent,her enemy. It should not, therefore, be neglected in any consideration of the influence operating to bring about her disobedience.

( I)P.I. 4, 608,9. 
Satan had heard in the previous afternoon's conversation of Eve's original enchantment with the image of her own beauty, and, Equatting at her ear while she slept, made use of his knowledge to stimulate her vanity and ambition thru the mysterious agency of dreams. In her slumbers the " spiritual creatures", of whom Adam had spoken, suddenly became gods desirous of looking upon the matchiess perfections of Eve. The one true god was forgotten by Eve, and her mind was filled with polytheistic ideas her sense of responsibility to her Maker vanished. Allured by the Tempter, she aspired to move thru the air, to enter Heaven, and Iive among the gods, herself a goddess. In her dream she took the forbidden fruit, rose to the sky and saw the great Farth beneath her; but there suddenly the gulde left her, and she sank again to the ground. The interruption of satan in his work of flattery and deception by the touch of Ithuriel's spear explains the unfinished appearance of her dream.

On the ninth day from the first arrival of satan in the Garden occurs the Temptation and Fall; for he has returned from encompasing the farth an has re-entered Paradise, (1), hiding himself in the serpent.(2). When "Nيw, whenas sacred light began to dawn In Eden on the humid flowers" (3), Adam and Eve come fort $h$ to begin the new day, (4), going
(1) P.I. IX.67-75
(2) P.I. IX. 179-91
(3) P.I. 9, $192-3$
(4) P.I. $192-99$ 
forth to their labors which Eve proposes to divide, Adam to go where cholce leads him, or where most needs, while she--

"In yonder spring of roses intermixed

With myrtle find what to redress till noon." (I). Adam at length yields to her request that they should beta e themselves separately to their tasks in the Garden; thus the serpent has the opportunity of tempting Eve alone. Eve's motive for separation, that the work of the Garden might be more expeditiously carried on, was in 1tself both innocent and commendable, but the suggestion of such a thing was out of harmony with her disposition, which was rather of a poetical than a practical cast. Even desire for solitude would have been admissable; but her impatience of restraint, her eager acceptance of Adam's reluctant consent, apparently indicated a condition other than that of perfect spiritual health. Adam's words are cautious, full of moral wisdom, and evident of a purpose to resist the adversary in whatever form he might appear; Eve's manifest self-confidence and a recklessness of the untried perils whose magnitude she could not guess. Adam, with a true manly jealousy and delicacy, wishes to be with Eve in order that he may resent any insult to her purity by even an attempt to seduce her from her obedience to God; Eve, on the other hand, seems to have lost all respect for that higher wisdom vested in Adam, preferring her own whim to his earnest conviction. 
We may almost question whether she did not dishonor God in forgetting her duty to her husband before she disobeyed him in taking the forbidden fruit. At all events, evil was in its nascent state. No authority had as yet been given to the husband to rule over the wife; he could only advise and reason with her: therefore to compel her stay by word or act would have been highly improper and the usurpation of a prerogative not his own. He is entirely relieved of the responsibility for her act : all the blame attaches to her; and the whole occurrence refers back to that uneasy dream of a week before.

We next behold her, "our general mother" "Veiled in a cloud of fragrence"( 1 ).

amid her favorite flowers, training them up and supporting them--

\section{"Mindless the while}

Herself, tho' fairest unsupported flower, From her best prop so far, and storm so nigh."(2). The sement makes his way to the place of her pleasant labor. Eve has just been compared to a wood-nympth the Delia's train" (3); hence it was unmistakably the passion of Apolio for Daphne that suggested to the poet that enchantment of Satan by Eve's beauty. The effect was such that

"That space the Evil One abstracted stood From his own evil, and for the time remained Stupidly good, of enmity disarmed, of guile, of hate, of envy, of revenge." (4). (1)P.I. 9,425 (2) P.I.9,431-33 (3) P.I. 9,387 (4) P.I.9, 463-66 
Yet this enchantment of beauty is soon overcome and Satan resumes active hostilities, glad of his oppurtunity in finding al one the weaker of the pair, as the greatest obstacle in the way of Satan's success had been Adam's intellectual and physical strength. The effect upon Eve of the serpent's flattery was immediate, but was for the time disguised by her amazement to hear a brute speaking at all. The lying spirit within the snake, unwilling to discover itself and aiming more carefully to conceal the fraud, pretended to those appetites which are known to belong to the serpent-kind, especially their predilection for

"The smell of sweetest fernel, or the teats Of ewe or goat, dropping with milk at even." (I). Professing thus to be true serpent, it remains for him only to account for his faculty of speech not possessed by the rest of the brute creation. Two important points were already gained: Eve's vanity was touched and her curiosity was excited. He had but to press these advantages and success was certain. For the latter he tells her that his intellectual advance came from eating the fruit of a certain tree in the Garden; for the former he praises her beauty and pretends to worship her as the most perfect being in Heaven or on Earth. He further tries to make her discontented with her retired life in the society of Adam a d holds out the hope of increased knowledge, power, and beauty, like those of the gods, to result from eating of

$$
\text { (I)-P.I. 9,58I,2 }
$$


the tree which had given such sapience to a brute. Eve recalls the prohibition with reference to the tree, a satan answers that the penalty denounced for disobedience does not follow, because he has eaten and yet lives. He urges ${ }_{n}$ the trespass is too petty for the notice of a God, and finally that the prohibition is an act of tyranny, intended to keep the human pair low and ignorant. The . Tempter's swift and sinuous course "in tangles" toward the Tree of Knowledge is an exact metaphorical image of his crooked, intricate, confusing, rapid method of false reasoning from ever-changing premises by which he misled the mind of Eve. Here we behold what Eve lost by being s eparated from her husband. Adam had seen God face to face, and would at once have convicted the lying spirit by his knowledge; but Eve had not seen him, and even when He brought her to Adam she was led by an invisible volce.

The falsehood and sophistry of satan soon prevailed with the woman, and the act of disobedience was not slow to follow.

\footnotetext{
"Her rash hand in evil hour Forthreaching to the fruit, in e plucked, she e at. Earth felt the wound, and Nature from her seat, sighing thru all her works, gave signs of woe That all was lost." (I)
}

Addis on pointed out an instance in the Aeneid, where, "when Dido yielded to the fatal temptation which ruined her 
Virgil tells us the earth trembled, the heavens were filled with flashes of Iightfning, and the nympths howled upon the mountal n-tops."

From the time of that first unquiet nigint, another passion, the desire of being admired, began to take possession of her soul, to assert its preeminence, and at last, stimulated by the sly serpent, wrought her fall. There is even a certan dramatic development in Eve's character; after she has eaten of the fruit, audacity ad deceit appear in her reflections; she meditates withholding from Adam the advantages of the tree, in order that she may become--

\section{"More equal, and perhaps--}

A thing not undesirable--sometimes

superior." (I).

It is easy to understand how tired Eve might well become, even before the fallacious fruit was eaten, of Adam's carefully maintained superiority. On thinking, however, of the judgment that in e may have to suffer, and of her own death, she resolves to draw him in, her motive being not fear, but a sudden movement of jealousy at the thot of

"Adam wedded to another Eve".

"This is as near an approach to drama in the handing of a human situation as is to be found in all Paradise Lost" (2). Henceforth Adam and Eve have all the failings and sorrows of human nature, and if sin is involved in our 
conception of humanity, they are now perfect members of the race. The relgn of evil passions has begun, and anger, hate, mistrust, suspicion, and discord arefiercely disturbing their minds and ready to burst forth to wreak their violence upon whatever may oppose them.

The thoughts and acts of the pair upon whose obedience the whole course of nature is depending expand into immeasurabi fimportance. Tho' these thoughts and acts differ in nothing from the ordinary domestic experiences of the most retirea of modern families, yet the infinitude of result following therefrom appears in such a way as to invest them with the highest sublimity. When righ tly judged, therefore, the poet can be charged with no descent from the great to the minute; for the motives, feelings, and acts of Adam and Eve are important in the high est degree, on account of their near association with the great event that transformed the world of happiness and beauty into one of misery and sin.

A change is wrought in the relation of Adam to Eve, of husband to wife. Before the Fall of man, the man was the recognized leader, counsellor, guide, but without the authority to $\infty \mathrm{mpel}$ obedience, and without the need of such authority; now fo $r$ the first time he was appointed ruler and could claim submission. This necessity followed from the discord introduced by sin, after which no two soul would ever so entirely accord upon all subjects as to make the existence of authority superfluous. Before the sin the two hearts beat as one, and their mutual love was sufficient to secure harmonious co-operation; now unity of purpose and action could be had only thru the exerciae 
of power. Thus the subjection of the woman to the will of her husband was not only a portion of her punishment for leading the way in disobedience, but was necessary to the very existence of future society.

Eve's distress and prayers form the most pathetic scene in the entire poem. Her penitence now manifests itself in the fact that she no longer accuses another,but takes the chief blame upon herself. She judges and condemns herself--the first step towards a better state of things. Her weeping speedily disarmed her husband of his anger:

"Soon his heart relented

Towards her, his life so late, and sole delight, Nor at his feet submissive in distress, -.

Creature so fair his reconcilement seeking, His counsel, whom she had displeased, his aid." (I). As she had taken the initiatory step towards disobedience En $d$ wrong, so she began first to manifest the temper upon which repentan ce and acceptance with God are founded. Adam was not long in following her example here as he had previously followed it in the transgression. Eve had seen the aggravation of her guilt in her double sin against God and her husband; Adam now saw the aggravation of his in his stronger nature and more direct responsibility. Wherever the guilt of the two is balanced, the one against the other, the man's is as heavy as the woman's, and he conducts himself in the calamity no more admirably than she. 
But, with all this, of our two grandparents Eve is the better drawn and the mar e human. Milton, no doubt, did not intend that it should be so, but he could not help it. One consequence of the doctrine

"He for God only, she for God in him"

is that Adam's single impulse of unselfishness, whereby he elects to share the offense and punishment of Eve, is a vice in him, a "bad o mpliance". Self-abnegation, the duty of Eve, is hardly within the right of Adam, and Dr. Johnston expressed a half-truth in violently paradoxical terms when he sald that Milton "though $t$ woman made only if $r$ obedience and man only for rebellion." It would be truer, and weaker, to say that Milton thought woman made to $r$ the exercise of private, and man for the exercise of public, virtues. Hence in their mutual relations Eve carries off all the honors, for her duty towards Adam coincides with her inclination, while in his case the two are at variance. There is no speech of Adam to be matched with the gleading intensity of Eve's appeal, be ginning--

"Forsake me not thus, Adam!" (I). and to her Milton commits the last and best speech spoken in Paradise:--

"But now lead on;

In me is no delay; with thee to go Is to sta here; without thee here to stay Is to go hence unwilling; thou to me Art all things under Heaven, all places thou, (1) P.I.I0, 914-36 
Who for my wilful cri me art banlshed hence.

This further consolation yet secure

I carry hence: tho' all by me is lost,

Such favor I unworthy am vouchafed,

By me the Promised seed shall all restore."(I).

She is generous and loving; her only reproach addressed to Adam is that he acceded to her request, and permitted her, on that fateful morning, to do her gardening alone, among the roses and myrties.

Such was Woman, such her role, in the four great world epics. In the Illad and Odyssey we see her reared in simple patriarchal surroundings,--respected, loved, a d honored, yet ever recognizing the authority of father husband, son, or captor. She is the incentive for both good and evil, for her men figt and die; for her they sing their words of praise. Surely the Homeric woman was the most blessed of all the epic wo men. As Virgil presents Woman, she is pre-eminently queen, capable of doing a man's worix creditably; but driven to self-destruction by the violent passions inspired by cupid. For her sake, Dante turned aside from the common herd to walk in paths of celestial mystery; for her beauty he strove to clothe himself with noble thoughts, love, and falth. Her he made his guide to Heaven, even to God himself. "And the first shall be last". Thru her the destinies of a whole race were flxed, bligh ted by her folly and her sin. Thru her the Sons of Man lost their right to live and be near God. 'Tho' all by her was lost, such favor she unworthy was vouch (1) P.I. 12, 614-2.3 


$$
82 .
$$

safed, by her the Promised seed shall all restore. 


\section{Bibllography}

Homer: Homer; Illad and Odyssey; Teubner Texts.

William פ. Glatone, Juventus Mundi; Macmillan

$$
\text { \& CO. } 1869 .
$$

W. C. Perry, The Women of Homer; Dodd, Mead \& Co. 1898.

T. D. Seymour, Iife in the Homeric Age; Macmillan

$$
\text { \& CO. } 1907 .
$$

Lang, Leaf, and Myers, The Iliad Homer;

$$
\text { Macmilian Co. } 1900 .
$$

Virgil: Knap Text; Scott, Foresman \& Co. 1900. H.S. Frieze, Complete Works of Virgil, Third Editin

$$
\text { D. Appleton \& Co. } 1889
$$

T. R. Glover, Virgil; The Nacmillan Co. 1912. J.W. Macki ${ }^{i}$, The Aeneid of Virgil; Macmillan \& CO. 1908.

N. W. DeWitt, The Dido Episode in the Aeneid of Virgiz Wm. Briggs, Toronto, 1907

J. R. Green, Stray Studies from England and Italy; Harper \& Brothers, 1876.

Dante: H.W. Longfellow, The Divine comedy of Dante Alighieri; Houghton, Mifflin \& Co. 1892. C. A. Dinsmore, Aids to the Study of Dante; Houghton, Mifflin \& Co. 1903. Wm. We Vernon, Readings on the Paradiso of Dante; Macmillan \& Co. 1909. 
J. A. Symonds, An Introduction to the study of Dante; Adam \& Charles Black, 1899. Karl Federn, Da te and his Time; McClure, Phillips \& Co. 1902 .

G. A. Scartazzini, A Companion to Dante; Macmillan \& Co. 1893.

Dan te, Convito; J. M. Den t \& Co. 1909.

Dante, Vita Nuova,--D. G. Rossetti, editor--Roberts Brothers, $188 \%$.

Milton: The Complete Poetical Works of John Milton;

Houghton, Mifflin Co. 1899.

J.A. Hemes, A Study of Milton's Paradise Lost;

J.B. I. ippencott \& Co. 1878.

Walter Raleigh, Milton; ‥ Arnold, 1909.

David Masson, Poetical works of John Milton-Vol:

III. Macmillan \& Co. 1890.

Richard Garnett, Life of John Milton; Walter scott, 1890.

Wm. P. Trent, John Milton; Macmillan Co. 1899.

H. W. Boynton, The World's Leading Poets;

Henry Holt \& Co. 1912. 


\section{The University of Missouri}

\section{Golumbia}

DEPARTMENT OF GREEK

May 23, 1916.

Professor Walter Mill ar, Dean,

Columbia, Mo.

Dear. Sir :

Herewith I hand you the thesis of Miss Lueile A. Carter with our approval.

Very truly yours,

W. Y.Manly. 


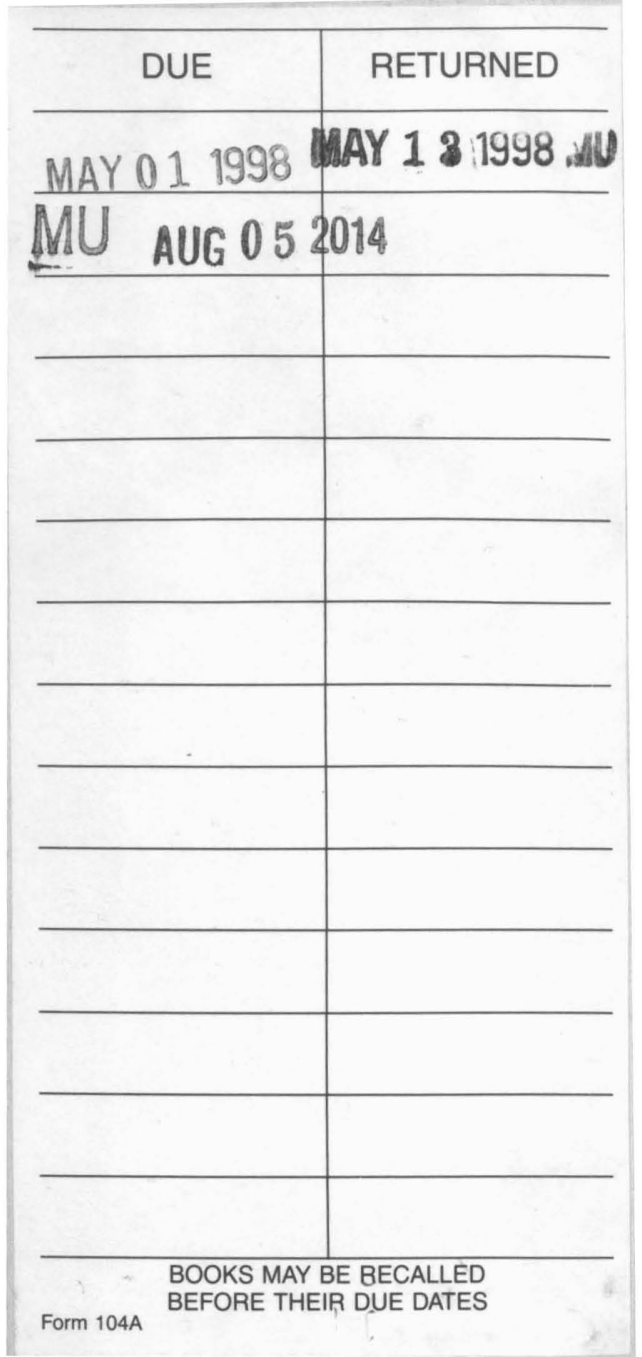




\section{$378.7 \mathrm{M71}$ OCT 20 ED XC246 UNIV.OF MO}

$378.7 \mathrm{M71}$

142552

XC246

Carter.

Woman in the epic. 

Wo manEpicspecs.t $x t$

MU Li braries

University of Missouri-.Col umbia

Digitization Information Page

Local identifier

Wo manEpic

Citation

AUTHOR

TI TLE

| MPRI NT

Carter, Lucile Armer.

Woman in the epic.

1916.

Capture information

Date captured

$04 / 2014$

Scanner manufacturer

Scanner model

Zeutschel

Scanning system software

OS 15000

Omniscan v.12.4 SR4 (1947) 64-bit

Optical resolution

Color settings

File types

Notes

$600 \mathrm{dpi}$

24 bit color

$\mathrm{tiff}$

some page curvature due to tight binding.

Source information

Content type

Format

Source I D

Notes

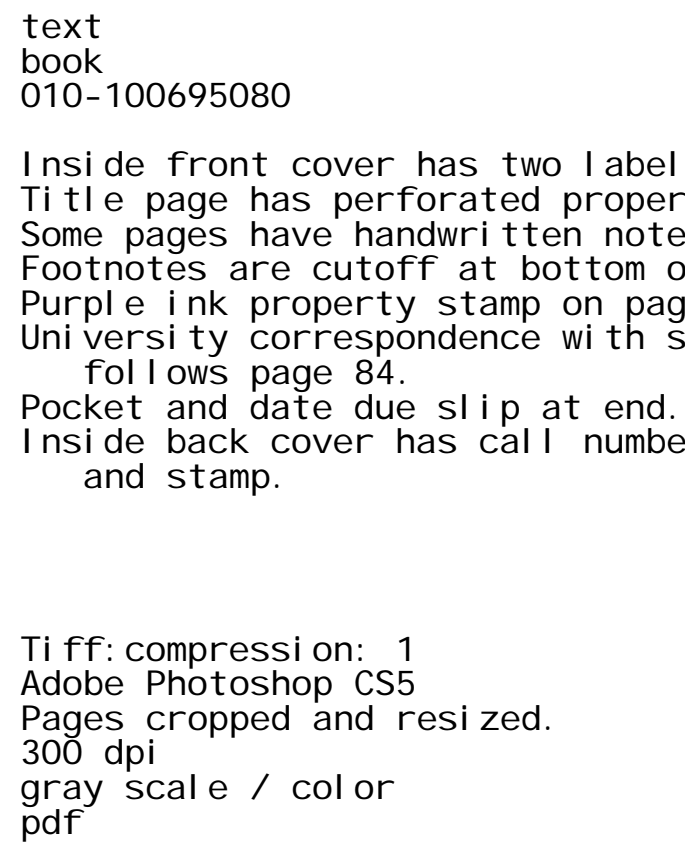

Tiff: compression: 1

Adobe Photoshop CS5

Pages cropped and resized.

$300 \mathrm{dpi}$

gray scale / color

$p d f$ 